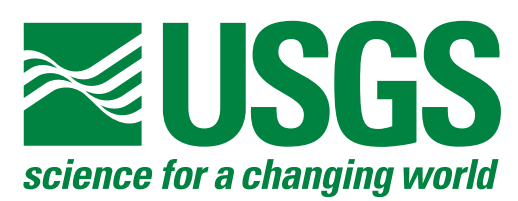

\title{
Using a Bayesian Network to Predict Shoreline-Change Vulnerability to Sea-Level Rise for the Coasts of the United States
}

By Benjamin T. Gutierrez, Nathaniel G. Plant, Elizabeth A. Pendleton, and E. Robert Thieler

Open-File Report 2014-1083

U.S. Department of the Interior

U.S. Geological Survey 


\section{U.S. Department of the Interior \\ SALLY JEWELL, Secretary}

\section{U.S. Geological Survey \\ Suzette M. Kimball, Acting Director}

U.S. Geological Survey, Reston, Virginia: 2014

For more information on the USGS-the Federal source for science about the Earth,

its natural and living resources, natural hazards, and the environment-visit

http://www.usgs.gov or call 1-888-ASK-USGS

For an overview of USGS information products, including maps, imagery, and publications, visit $h$ ttp://www.usgs.gov/pubprod

To order this and other USGS information products, visit http://store.usgs.gov

Any use of trade, firm, or product names is for descriptive purposes only and does not imply endorsement by the U.S. Government.

Although this information product, for the most part, is in the public domain, it also may contain copyrighted materials as noted in the text. Permission to reproduce copyrighted items must be secured from the copyright owner.

Suggested citation:

Gutierrez, B.T., Plant, N.G., Pendleton, E.A., and Thieler, E.R., 2014, Using a Bayesian Network to predict shoreline change vulnerability to sea-level rise for the coasts of the United States: U.S. Geological Survey Open-File Report 2014-1083, 26 p., http://dx.doi.org/10.3133/ofr20141083.

ISSN 2331-1258 (online) 


\section{Contents}

Abstract

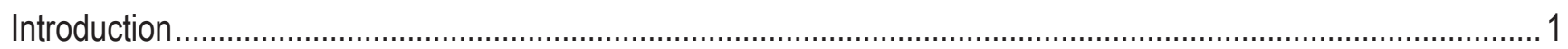

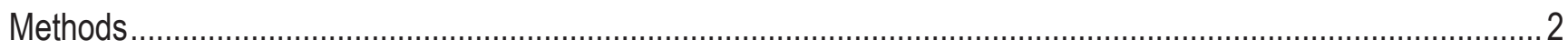

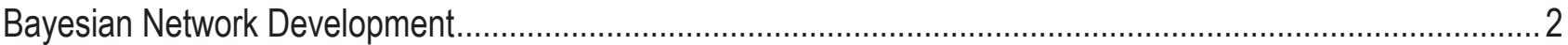

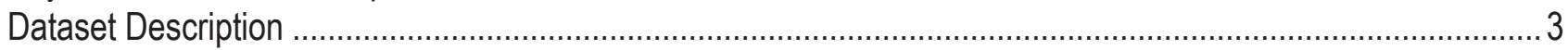

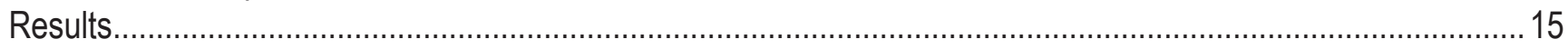

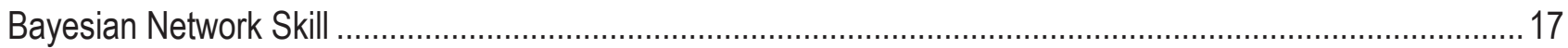

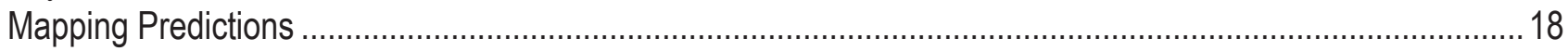

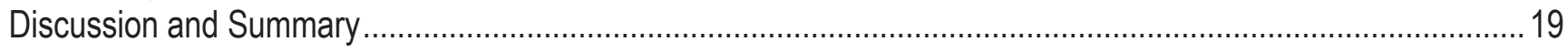

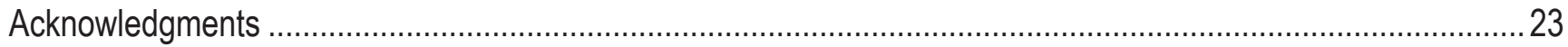

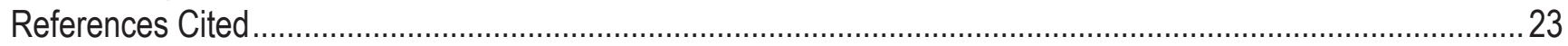

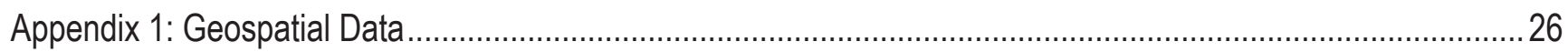

\section{Figures}

1. The structure of the Bayesian Network (BN) used for this study ...........................................................

2. Map of relative sea-level rise classes for the coast of the continental United States showing the extent

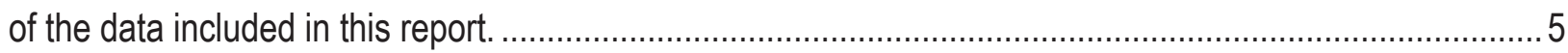

3. Map of relative sea-level rise classes for the coasts of Alaska and Hawaii showing the extent of the data included in this report ..................................................................................................

4. Map of average significant wave height classes for the coast of the continental United States showing the extent of the data included in this report ......................................................................................

5. Map of average significant wave height classes for the coasts of Alaska and Hawaii showing the extent of the data included in this report.

6. Map of tidal range classes for the coast of the continental United States showing the extent of the data included in this report.

7. Map of tidal range classes for the coasts of Alaska and Hawaii showing the extent of the data included in this report.

8. Map of geomorphology classes for the coast of the continental United States showing the extent of the data included in this report

9. Map of geomorphology classes for the coasts of Alaska and Hawaii showing the extent of the data included in this report.

10. Map of coastal slope classes for the coast of the continental United States showing the extent of the data included in this report

11. Map of coastal slope classes for the coasts of Alaska and Hawaii showing the extent of the data included in this report.

12. Map of shoreline-change rate classes for the coast of the continental United States showing the extent of the data included in this report 
13. Map of shoreline-change rate classes for the coasts of Alaska and Hawaii showing the extent of the data included in this report

14. Maps of the continental U.S. coasts showing the posterior probability of shoreline-change rates $<-1 \mathrm{~m} / \mathrm{yr}$.

15. Maps of Alaska and Hawaii showing the posterior probability of shoreline-change rates $<-1 \mathrm{~m} / \mathrm{yr}$.

16. Maps of the continental U.S. coasts showing the probability of the most likely shoreline-change rate........21

17. Maps of Alaska and Hawaii showing the probability of the most likely shoreline-change rate 22

\section{Tables}

1. Variables used in the Bayesian Network.

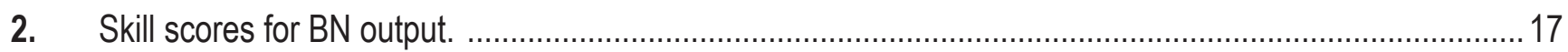

3. Percent of coast where shoreline-change rate indicating erosion (at least $-1 \mathrm{~m} / \mathrm{yr}$ ) is likely (probability of at least 67 percent). 


\section{Conversion Factors}

\begin{tabular}{ccc}
\multicolumn{1}{l}{ Inch/Pound to SI } & & \\
\hline Multiply & By & To obtain \\
\hline & Length & \\
\hline inch (in.) & 2.54 & centimeter $(\mathrm{cm})$ \\
inch (in.) & 25.4 & millimeter $(\mathrm{mm})$ \\
foot (ft) & 0.3048 & meter $(\mathrm{m})$ \\
mile (mi) & 1.609 & kilometer $(\mathrm{km})$ \\
yard (yd) & 0.9144 & meter $(\mathrm{m})$ \\
\hline & Rate & \\
\hline inch per year (in/yr) & 25.4 & millimeter per year $(\mathrm{mm} / \mathrm{yr})$ \\
foot per year (ft/yr) & 0.3048 & meter per year $(\mathrm{m} / \mathrm{yr})$ \\
\hline
\end{tabular}




\title{
Using a Bayesian Network to Predict Shoreline-Change Vulnerability to Sea-Level Rise for the Coasts of the United States
}

\author{
By Benjamin T. Gutierrez, Nathaniel G. Plant, Elizabeth A. Pendleton, and E. Robert Thieler
}

\begin{abstract}
Sea-level rise is an ongoing phenomenon that is expected to continue and is projected to have a wide range of effects on coastal environments and infrastructure during the 21 st century and beyond. Consequently, there is a need to assemble relevant datasets and to develop modeling or other analytical approaches to evaluate the likelihood of particular sea-level rise impacts, such as coastal erosion, and to inform coastal management decisions with this information. This report builds on previous work that compiled oceanographic and geomorphic data as part of the U.S. Geological Survey's Coastal Vulnerability Index (CVI) for the U.S. Atlantic coast, and developed a Bayesian Network to predict shoreline-change rates based on sea-level rise plus variables that describe the hydrodynamic and geologic setting. This report extends the previous analysis to include the Gulf and Pacific coasts of the continental United States and Alaska and Hawaii, which required using methods applied to the USGS CVI dataset to extract data for these regions. The Bayesian Network converts inputs that include observations of local rates of relative sea-level change, mean wave height, mean tide range, a geomorphic classification, coastal slope, and observed shoreline-change rates to calculate the probability of the shoreline-erosion rate exceeding a threshold level of 1 meter per year for the coasts of the United States. The calculated probabilities were compared to the historical observations of shoreline change to evaluate the hindcast success rate of the most likely probability of shoreline change. Highest accuracy was determined for the coast of Hawaii (98 percent success rate) and lowest accuracy was determined for the Gulf of Mexico ( 34 percent success rate). The minimum success rate rose to nearly 80 percent (Atlantic and Gulf coasts) when success included shoreline-change outcomes that were adjacent to the most likely outcome. Additionally, the probabilistic approach determines the confidence in calculated outcomes as the probability of the most likely outcome. The confidence was highest along the Pacific coast and it was lowest along the Alaskan coast.
\end{abstract}

\section{Introduction}

Rising sea levels in the next 50-100 years will affect coastal regions over a large part of the globe (IPCC, 2007a; NCA, 2013). Because of a combination of climatic, oceanographic, and geologic factors, the rate of sea-level rise will vary along different stretches of the Nation's (and global) coastline and as a result these factors can affect the rate of shoreline change. Hence, developing the capability to forecast shoreline changes on time-scales of 50-100 years has been an important goal to inform coastal management decisions (Leatherman, 2001; CCSP, 2009; NCA, 2013). There are a number of approaches that can be applied to forecast shoreline changes (Leatherman, 2001; Gutierrez and others, 2009). In previous work (Gutierrez and others, 2011a and 2011b) an approach using a Bayesian Network (BN) was developed that used previously published U.S. Geological Survey (USGS) coastal vulnerability index (CVI) datasets (Thieler and Hammar-Klose, 1999; Hammar-Klose and Thieler, 2001) to identify and evaluate the potential for future shoreline changes. Gutierrez and others (2011a) demonstrated that BNs provide a useful method to evaluate relations between forcing factors (for example, rate of 
sea-level rise, wave height, or tidal range), and shoreline-change rate. Gutierrez and others (2011a) also demonstrated that the probabilistic output from the BN approach provides a way to calculate and communicate outcome uncertainty quantitatively using specific probability levels (for example, 90 percent, corresponding to the threshold between "likely" and "very likely"; IPCC, 2007b).

In this report, we describe the methods, data, and results developed in an application of the BN shoreline-change prediction to much of the U.S. coastline. As in the Atlantic Coast application (Gutierrez and others, 2011a and 2011b), the data from the Gulf and Pacific coasts were extracted from the CVI. In addition, data from Alaska and Hawaii were included that were prepared according to the methods described in the earlier reports. In a skill assessment, we evaluate how well the BN predicted shoreline-change rates. This report presents shoreline-change rate probabilities calculated with the $\mathrm{BN}$ approach illustrating (1) the likelihood of the erosion rate exceeding a -1 meter per year (m/yr) erosionrate threshold and (2) the confidence of the most likely erosion rate prediction. The geospatial data that supports these calculations and results for the continental United States, Alaska, and Hawaii are included as well.

\section{Methods}

The methods require development of a $\mathrm{BN}$ that is calibrated using a large dataset. We describe the details of the $\mathrm{BN}$ development and then the details of the datasets.

\section{Bayesian Network Development}

A Bayesian Network provides a framework to evaluate the probability of a specific response outcome, shoreline-change rates in our case, based on correlation relations between the response variable and other variables related to the response. Bayes' Theorem relates the probability of one event $R$ given the occurrence of another event $O$ (Bayes, 1763; Gelman and others, 2004; Jensen and Nielsen, 2007):

$$
p\left(R_{i} \mid O_{j}\right)=\frac{p\left(O_{j} \mid R_{i}\right) \cdot p\left(R_{i}\right)}{p\left(O_{j}\right)}
$$

On the left side of this equation, $p\left(R_{i} \mid O_{j}\right)$ is the conditional probability of a particular response, $R_{i}$, given an observation scenario $O_{j}$. For example, the response could be a shoreline-change rate that coincides with one of $i$ possible outcome scenarios (for example, accretion, no-change, or severe erosion). Likewise, the $j^{\text {th }}$ observation could be a particular scenario from a set of possible observations of wave height, rate of sea-level rise, and geomorphic setting. On the right side of this equation, $p\left(O_{j} \mid R_{i}\right)$ is the likelihood of the observation scenario for a known response. This term indicates the strength of the correlation between observation and response describing, for example, the relation between the rate of sea-level rise and shoreline change. The correlation is high if the observations are accurate and if response variables are sensitive to the observed variables. The second term in the numerator is the prior probability, that is, the likelihood of extreme erosion based on all previous observations from the U.S. coastline. The term in the denominator is a normalization factor to account for the likelihood of the particular observation scenario.

We constructed a BN using the Norsys software package Netica (Norsys, 1992-2009) targeting prediction of long-term shoreline-change rates, estimated over 50 to 100 year time periods. Oceanographic variables (tide range, mean wave height, and sea-level rise), and geomorphic variables (coastal slope, geomorphic setting, and shoreline-change rate) are included. The correlation relations 
between the variables are represented as interconnected nodes (fig. 1). Each node (that is, variable) is resolved by either five or six classes (see table 1) representing the range of scenarios spanned by the dataset. The connections between nodes reflect our understanding of how the variables are related to each other and how they affect long-term shoreline change. For example, in the BN used here (fig.1), the sea-level rise rate is assumed to exert an effect on the geomorphic setting and the shoreline-change rate. The conditional probabilities that relate the variables to each other are estimated from existing data (for example, the CVI datasets). Once trained on data, the BN can be used to make probabilistic predictions even for cases where some inputs to the BN are missing from the dataset. For example, in this analysis, shoreline-change data were not available for large parts of Alaska and Hawaii. Even so, the BN was used to make shoreline-change rate predictions using the inputs for these regions and the correlations that were learned from all regions with more complete datasets.

\section{Dataset Description}

The dataset used in this study includes that published in (Gutierrez and others, 2011b), which was based on data from (Thieler and Hammar-Klose, 1999) and data from Gulf and Pacific coasts (Hammar-Klose and Thieler, 2001) of the United States, and newer data obtained for Alaska and Hawaii using the methodology of Thieler and Hammar-Klose (1999) and Hammar-Klose and Thieler (2001) (fig. 1; table 1). Although the variables within each of the datasets are all identically defined, there are differences in the spatial resolution of each dataset. The Hammar-Klose and Thieler (2001) data were sampled at about 5-kilometer $(\mathrm{km})$ resolution along the shoreline. Data compiled for Alaska and Hawaii were stored at approximately 1-km scale. The input data include the ocean-facing shores of the U.S.

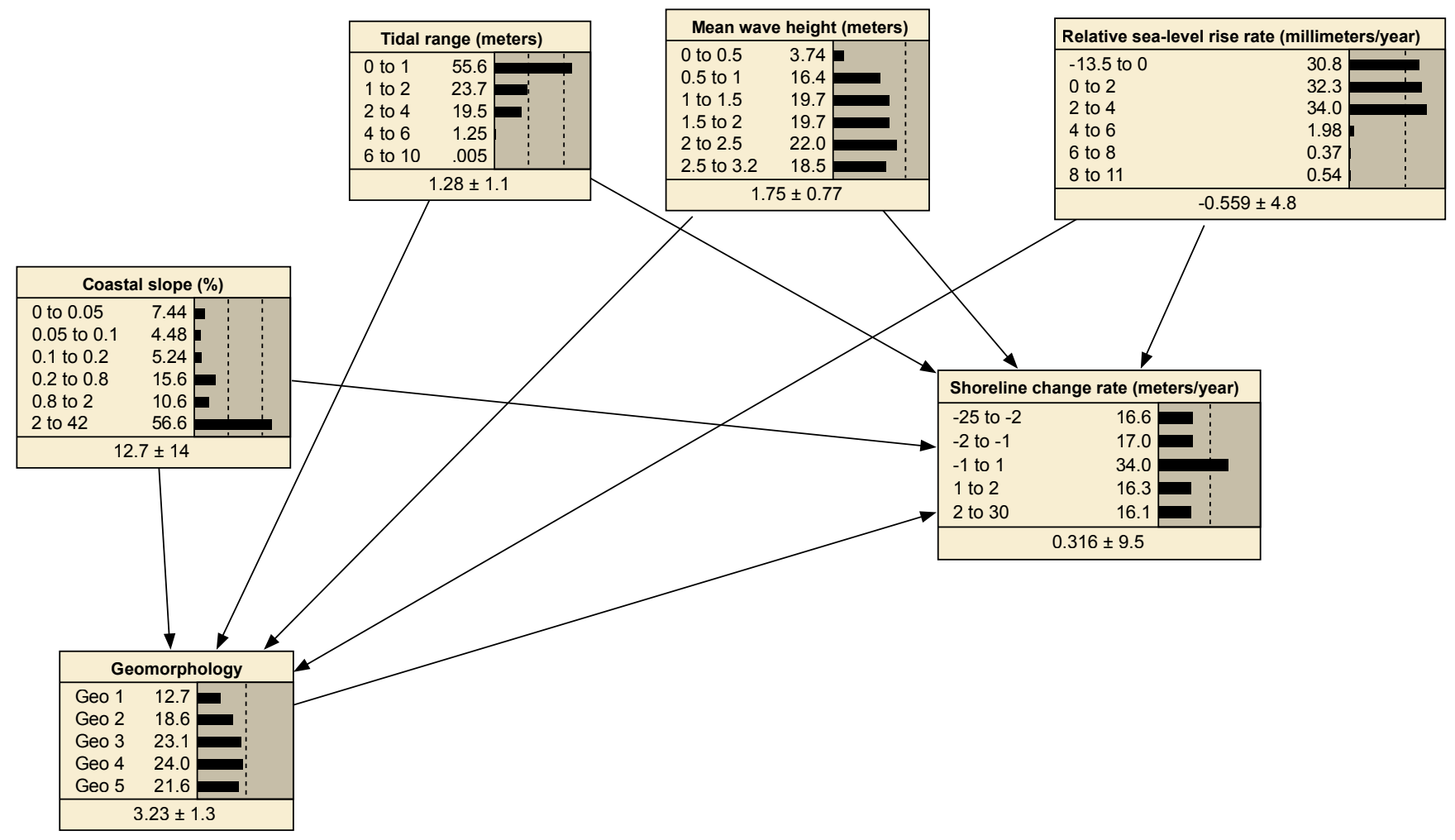

Figure 1. The structure of the Bayesian Network (BN) used for this study. The rate of relative sea-level rise, mean wave height, and tidal range were assumed to be driving forces, the coastal slope and geomorphic setting were assumed to be geological constraints, and the shoreline-change rate is predicted. 
Atlantic Coast from the Canadian border to Key West, Florida; parts of Chesapeake and Delaware Bays; the ocean-facing Pacific and Gulf coasts; and the ocean-facing coasts of Alaska and Hawaii. For the present application, data in each node of the BN were reclassified to span the range of values that resulted by combining data from each of these coasts. The expanded range of some of the variables (sea-level rise, wave height, and slope) required adding a sixth bin (table 1) to maintain adequate resolution in the $\mathrm{BN}$.

Table 1. Variables used in the Bayesian Network.

[( ) denote number of values for each variable occurring within the corresponding bin; ${ }^{1}$ na-not applicable; (m/yr) meters per year; (mm/yr) millimeters per year; . (m) meters]

\begin{tabular}{|c|c|c|c|c|c|c|}
\hline \multirow{2}{*}{ Variable } & \multicolumn{6}{|c|}{ Binned Values } \\
\hline & 1 & 2 & 3 & 4 & 5 & 6 \\
\hline \multirow[t]{2}{*}{ Geomorphology } & $\begin{array}{c}1- \\
\text { Rocky, cliffed } \\
\text { coasts, fjords }\end{array}$ & $\begin{array}{l}\quad 2- \\
\text { Medium cliffs, } \\
\text { indented coasts }\end{array}$ & $\begin{array}{c}3- \\
\text { Low cliffs, glacial } \\
\text { drift, alluvial } \\
\text { plains }\end{array}$ & $\begin{array}{c}4- \\
\text { Cobble beaches, } \\
\text { estuarine and } \\
\text { lagoonal coasts }\end{array}$ & $\begin{array}{c}5- \\
\text { Barrier beaches, } \\
\text { sand beaches, salt } \\
\text { marsh, mud flats, } \\
\text { deltas, mangroves, } \\
\text { coral reefs }\end{array}$ & $n a^{1}$ \\
\hline & (740) & (951) & $(5848)$ & (4888) & $(8485)$ & \\
\hline \multirow[t]{2}{*}{ Shoreline Change (m/yr) } & $>2.0$ & $1.0-2.0$ & -1.0 to 1.0 & -2.0 to -1.0 & $<-2.0$ & na \\
\hline & (168) & (215) & $(4015)$ & (456) & (1555) & \\
\hline \multirow[t]{2}{*}{ Coastal Slope (percent) } & $<0.05$ & 0.05 to 0.1 & 0.1 to 0.2 & 0.2 to 0.8 & 0.8 to 2.0 & $>2.0$ \\
\hline & (1594) & (951) & (1121) & (3329) & (2268) & (12098) \\
\hline \multirow[t]{2}{*}{ Relative Sea-Level Change ( $\mathrm{mm} / \mathrm{yr})$} & $<0$ & 0 to 2 & 2 to 4 & 4 to 6 & 6 to 8 & 8 to 11 \\
\hline & (7106) & $(7523)$ & (7806) & $(442)$ & $(90)$ & (117) \\
\hline \multirow[t]{2}{*}{ Mean Wave Height (m) } & 0 to 0.5 & 0.5 to 1 & 1.0 to 1.5 & 1.5 to 2 & 2 to 2.5 & $>2.5$ \\
\hline & (928) & $(4540)$ & (4239) & $(4652)$ & (5308) & $(4339)$ \\
\hline \multirow[t]{2}{*}{ Mean Tidal range (m) } & 0 to 1 & 1 to 2 & 2 to 4 & 4 to 6 & $>6$ & na \\
\hline & $(16275)$ & $(3665)$ & $(3757)$ & (239) & 0 & \\
\hline
\end{tabular}

Although the descriptions of the variables and methods of extracting them from existing datasets are described in the earlier publications (Thieler and Hammar-Klose, 1999; Hammar-Klose and Thieler, 2001; Gutierrez and others, 2011b), we repeat some of the descriptions here to clarify how data from different coastal regions and different spatial resolution were assimilated for this national-scale application.

Relative sea-level rise rate.-This is the rate of sea-level rise relative to local land motion, computed by fitting a linear trend to National Ocean Service (NOS) long-term (50-100+ years) tide gage observations and interpolating alongshore between stations (figs. 2 and 3). Sea-level rise values for Alaska and Hawaii were computed using the same methods based on local NOS tide gages. For Hawaii, we were able to compute long-term sea-level rise values based on tide gages with records exceeding 50 years (NOS stations: 161140, Nawiliwili; 1612340, Honolulu; 1615680, Kahului; and 1617760, Hilo). In the case of the northern Alaskan coast, tide gages in this region were sparse. Consequently, 


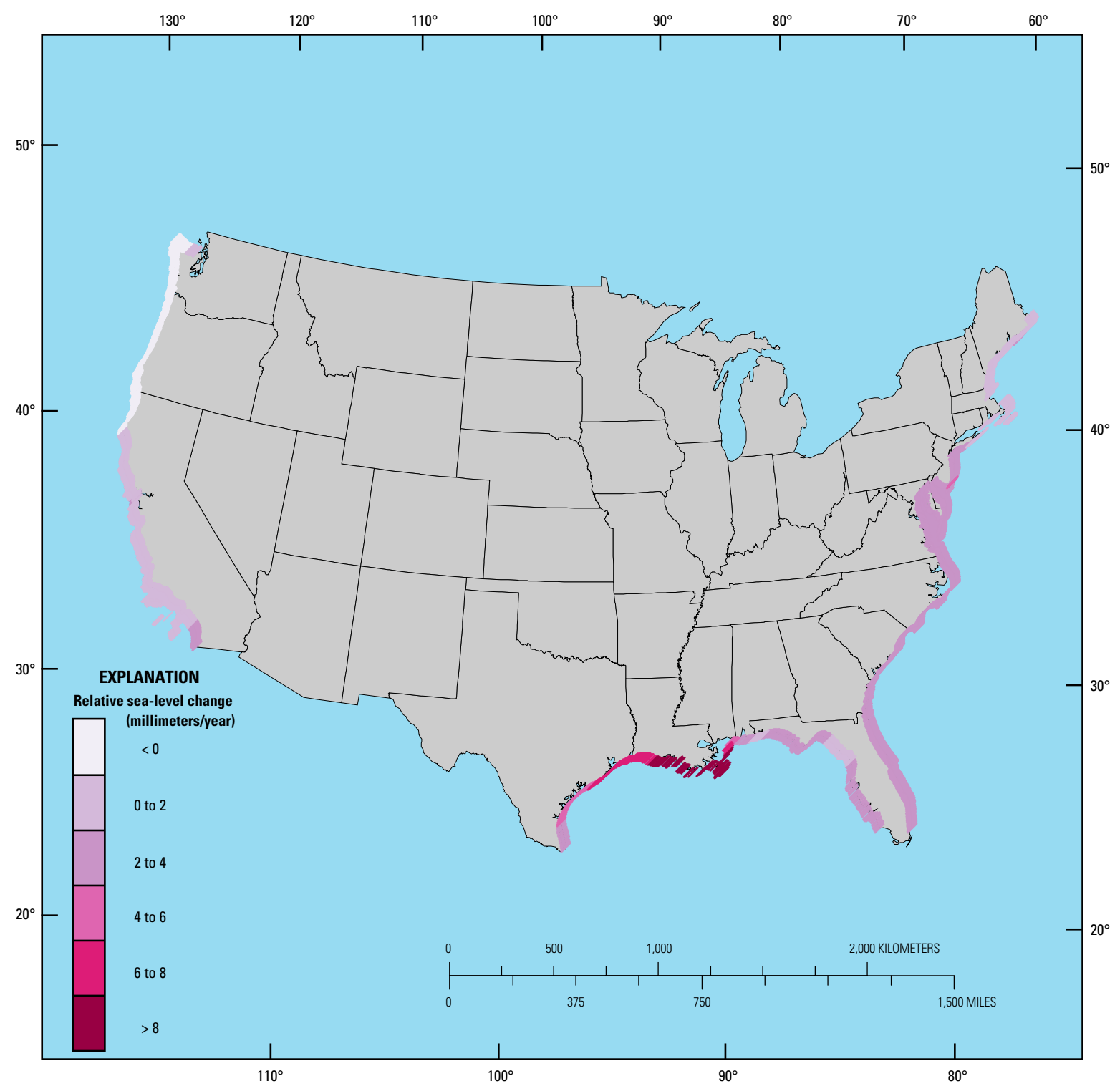

Figure 2. Map of relative sea-level rise classes for the coast of the continental United States showing the extent of the data included in this report. Color scheme defined using Brewer (2013).

we relied on records of varying length (20-60 years) from the North Slope of Alaska and Russia, available through the NOS and Permanent Service for Mean Sea-Level (Holgate and others, 2013; PSMSL, 2013). The Russian gages included the following (gages not shown): Vankarem 2.91 millimeter per year (mm/yr); Vrangelia (2.59 mm/yr), Netten (2.16 mm/yr); Mys Shmidta (1.88 mm/yr); Providenia (3.52 mm/yr); Koluchin (2.64 mm/yr) (Holgate and others, 2013; PSMSL, 2013).

Mean wave height.-The long-term mean offshore wave height computed from U.S. Army Corps of Engineers Wave Information Studies (WIS) hindcast data (CVI data from Hubertz and others, 1996; Alaska and Hawaii data from WIS, 2013). For each WIS station nearest to the coastline, the mean wave height for a 20-to-24-year period was computed and associated with a nearest shoreline point. Then, the mean wave height was interpolated alongshore to the other shoreline points included in the CVI dataset (figs. 4 and 5). 
A

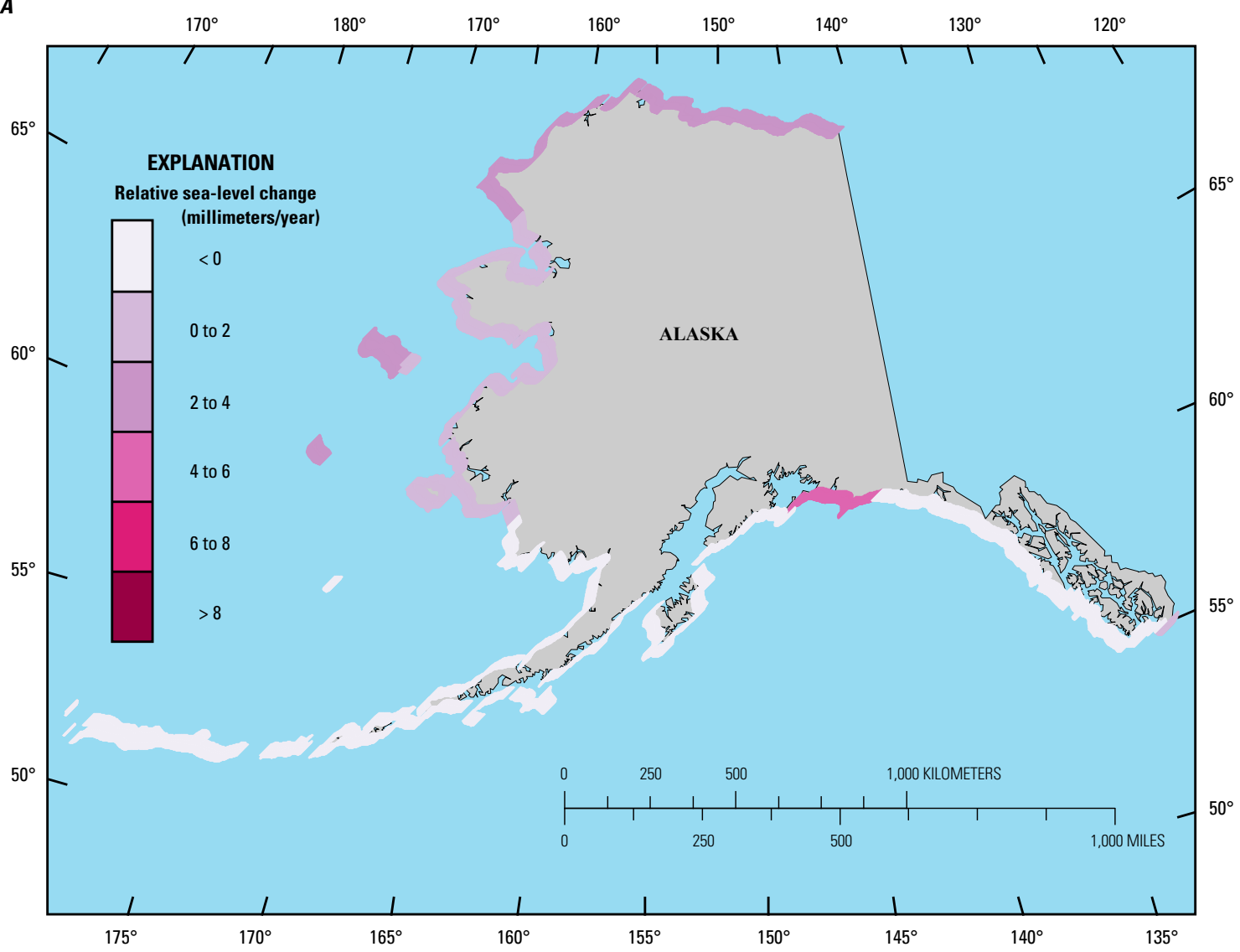

B

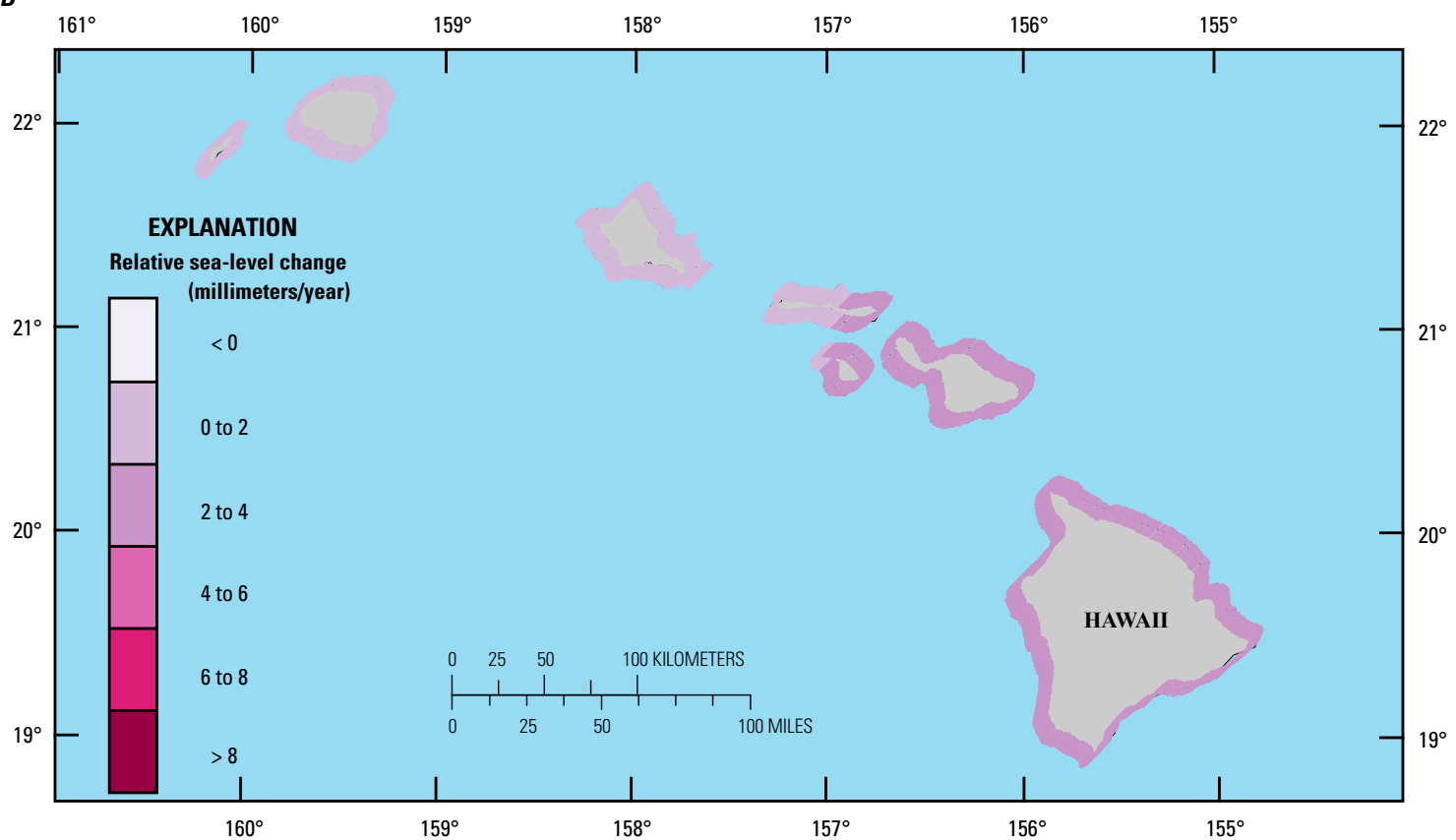

Figure 3. Map of relative sea-level rise classes for the coasts of Alaska $A$ and Hawaii $B$ showing the extent of the data included in this report. Color scheme defined using Brewer (2013). 


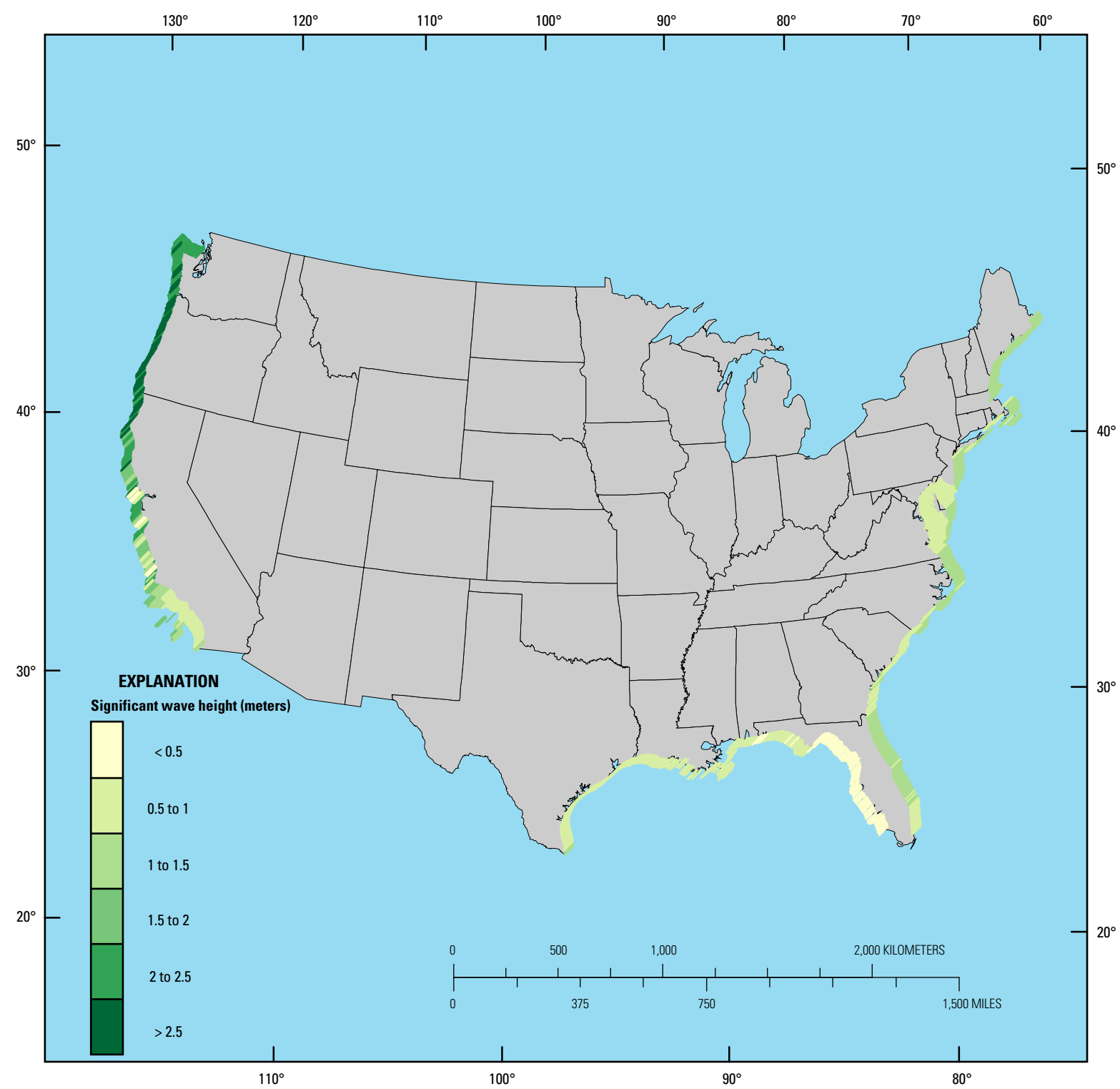

Figure 4. Map of average significant wave height classes for the coast of the continental United States showing the extent of the data included in this report. Color scheme defined using Brewer (2013).

Mean tidal range.- The long-term mean range of the tidal water level variations computed from NOS tide gages (National Ocean Service, 2013) and interpolated alongshore between stations (figs. 6 and 7). These tidal datum values for mean high water (MHW) and mean low water (MLW) were associated with each shoreline data point used to approximate the tidal range at that location (Thieler and HammarKlose, 1999; Hammar-Klose and Thieler, 2001). Tidal data for Alaska were obtained from 448 NOS stations and tidal range values were gridded and interpolated along the shoreline data used for this study. For Hawaii, 34 NOS stations were incorporated using the same method (National Ocean Service, 2013).

Geomorphic setting.-A classification of the geomorphic and related geologic and oceanographic processes that might control shoreline change (figs. 8 and 9). We simplified the Thieler and HammarKlose (1999) definitions such that geomorphic settings convey only morphologic conditions without explicit reference to levels of vulnerability (table 1). No CVI-compatible geomorphic classifications 

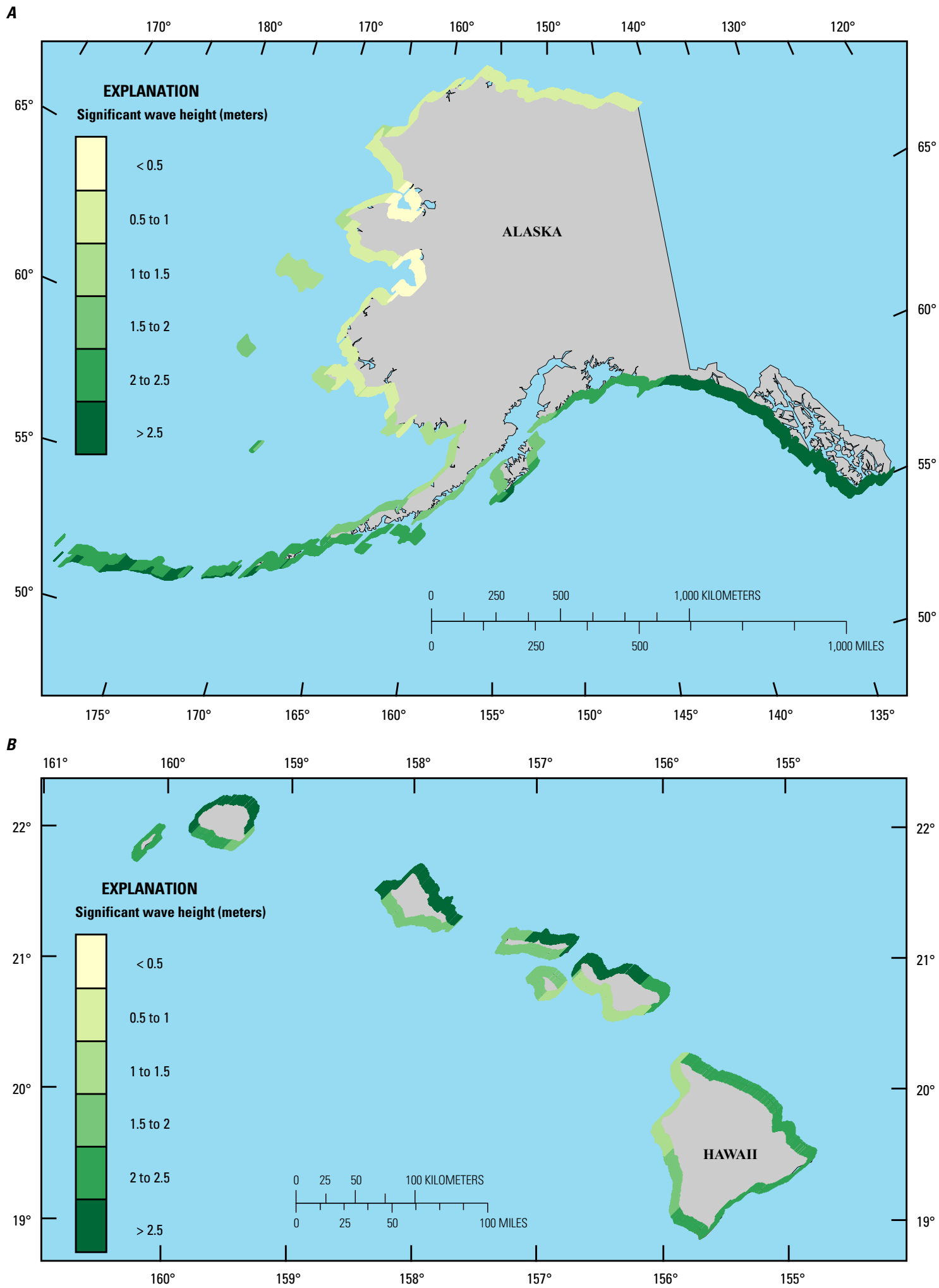

Figure 5. Map of average significant wave height classes for the coasts of Alaska $A$ and Hawaii $B$ showing the extent of the data included in this report. Color scheme defined using Brewer (2013). 


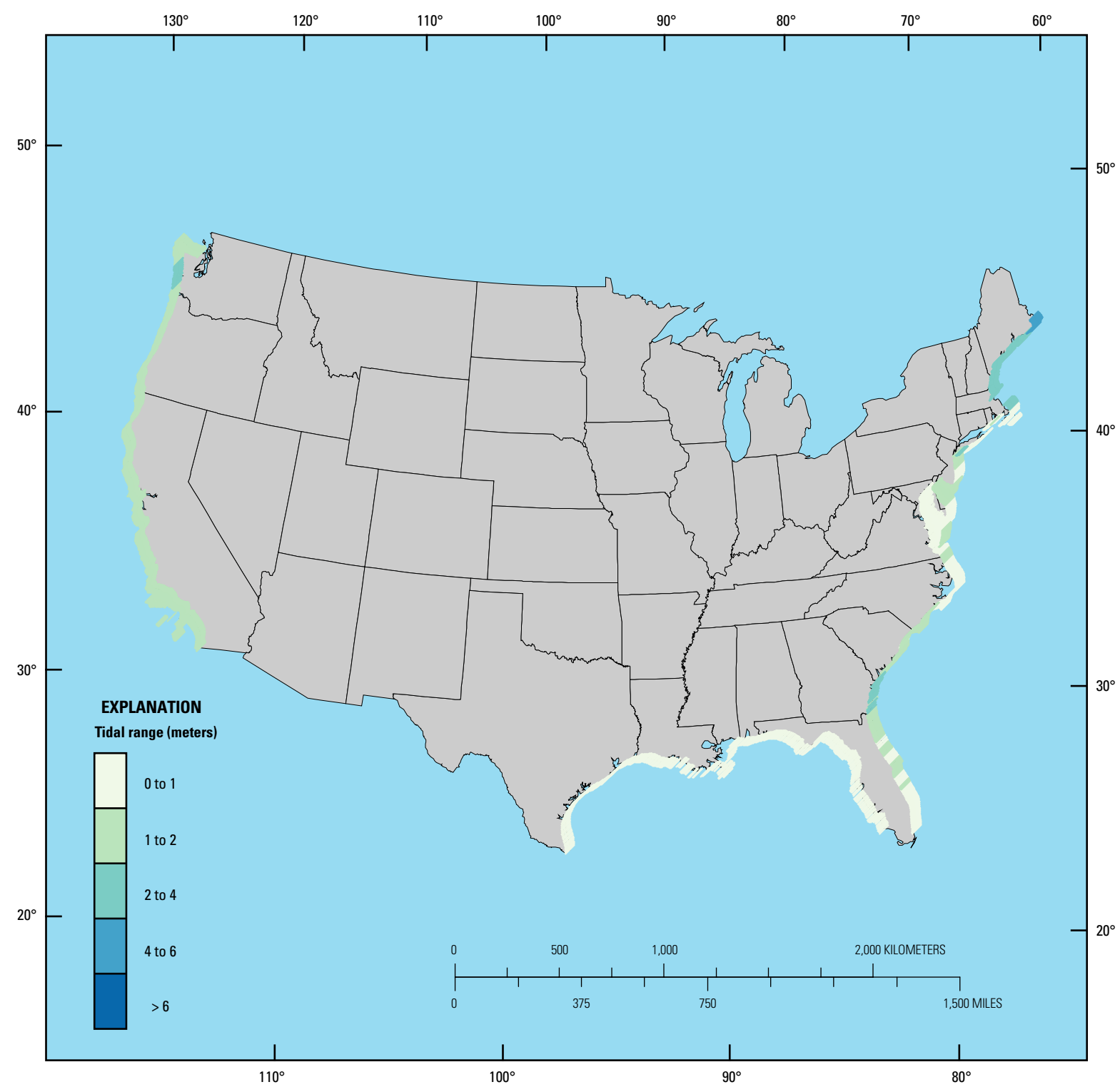

Figure 6. Map of tidal range classes for the coast of the continental United States showing the extent of the data included in this report. Color scheme defined using Brewer (2013).

existed for Alaska and Hawaii, so we developed these by applying the definitions to USGS Geologic Maps (Hawaii; Sherrod and others, 2007), coastal landform datasets, (Alaska; USGS, 1996) and aerial photography available through Google Earth and the ESRI WorldWide as a guide.

Coastal slope.-The continental slope is used to distinguish differences in geologic and tectonic settings. Computed from gridded National Geophysical Data Center and U.S. Navy topographic and bathymetric elevation data extending approximately $50 \mathrm{~km}$ landward and seaward of the local shoreline for the Atlantic Coast and approximately $10 \mathrm{~km}$ landward and seaward of the local shoreline for the Gulf and Pacific coasts (Hammar-Klose and Thieler, 2001)(figs. 10 and 11). For Alaska and Hawaii, coastal slope was computed using the same methods reported in (Hammar-Klose and Thieler, 2001) but using elevation and bathymetric data within $10 \mathrm{~km}$ of the shoreline. Elevation data from the ETOPO 1 Global 
A

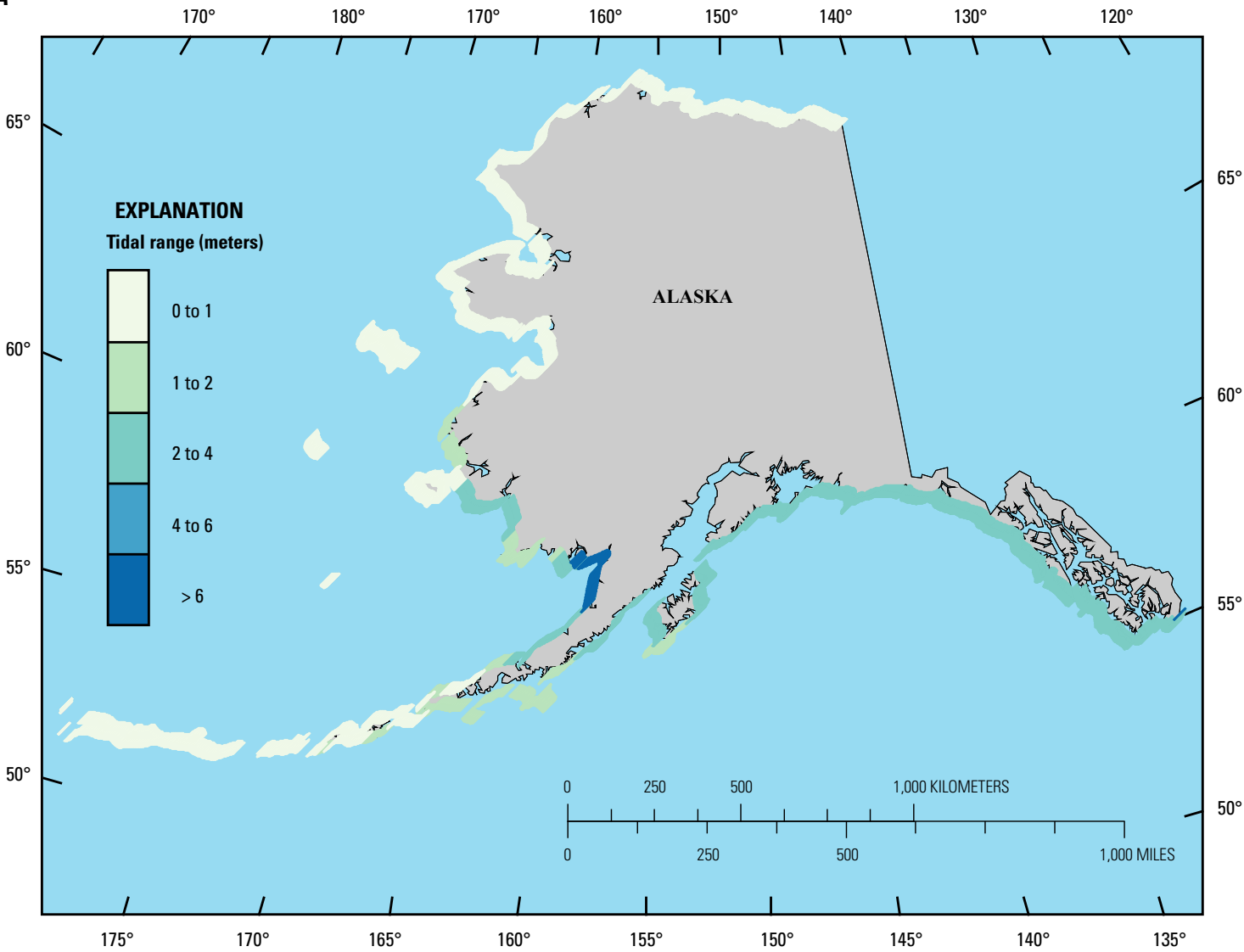

B

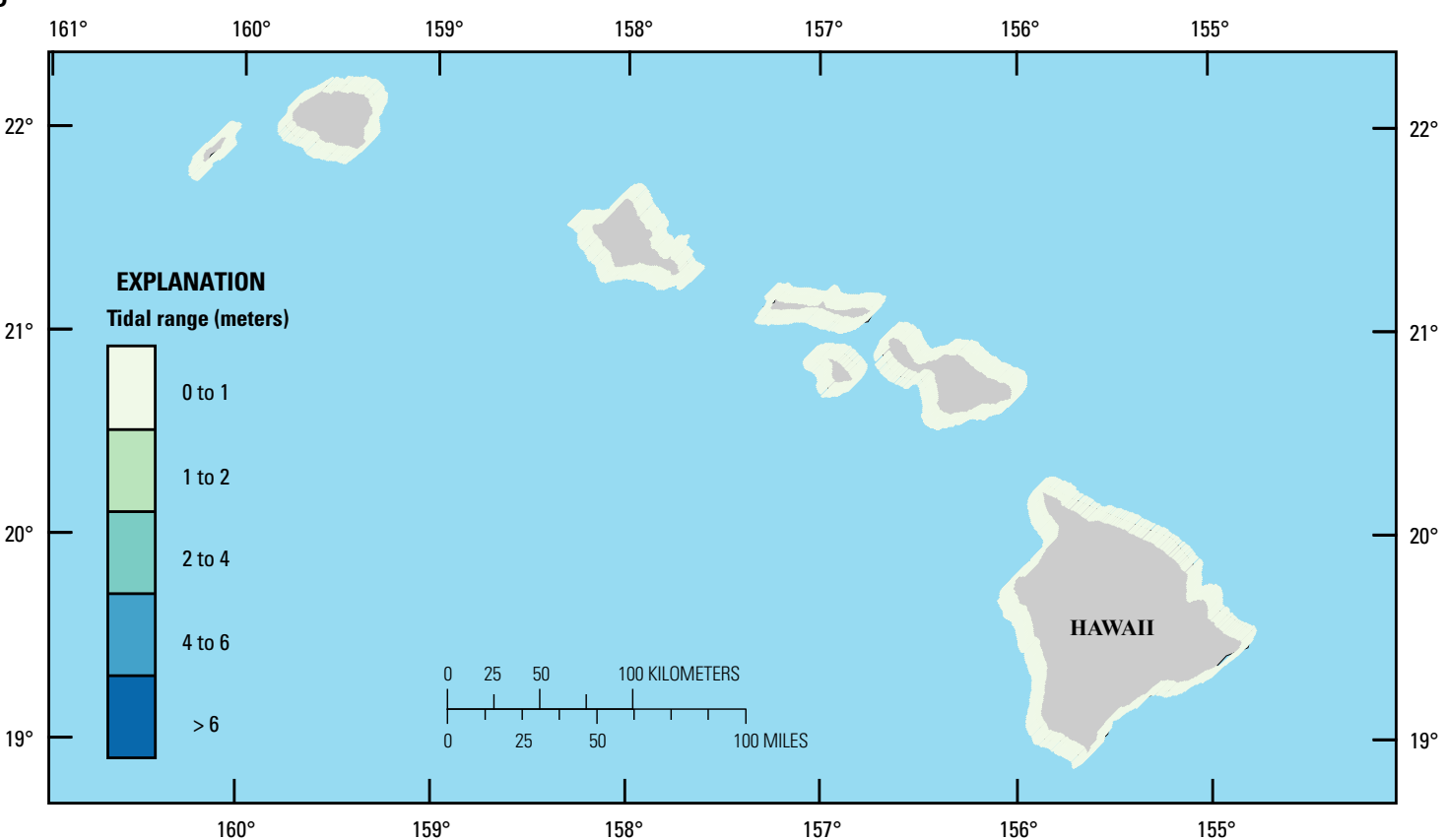

Figure 7. Map of tidal range classes for the coasts of Alaska $A$ and Hawaii $B$ showing the extent of the data included in this report. Color scheme defined using Brewer (2013). 


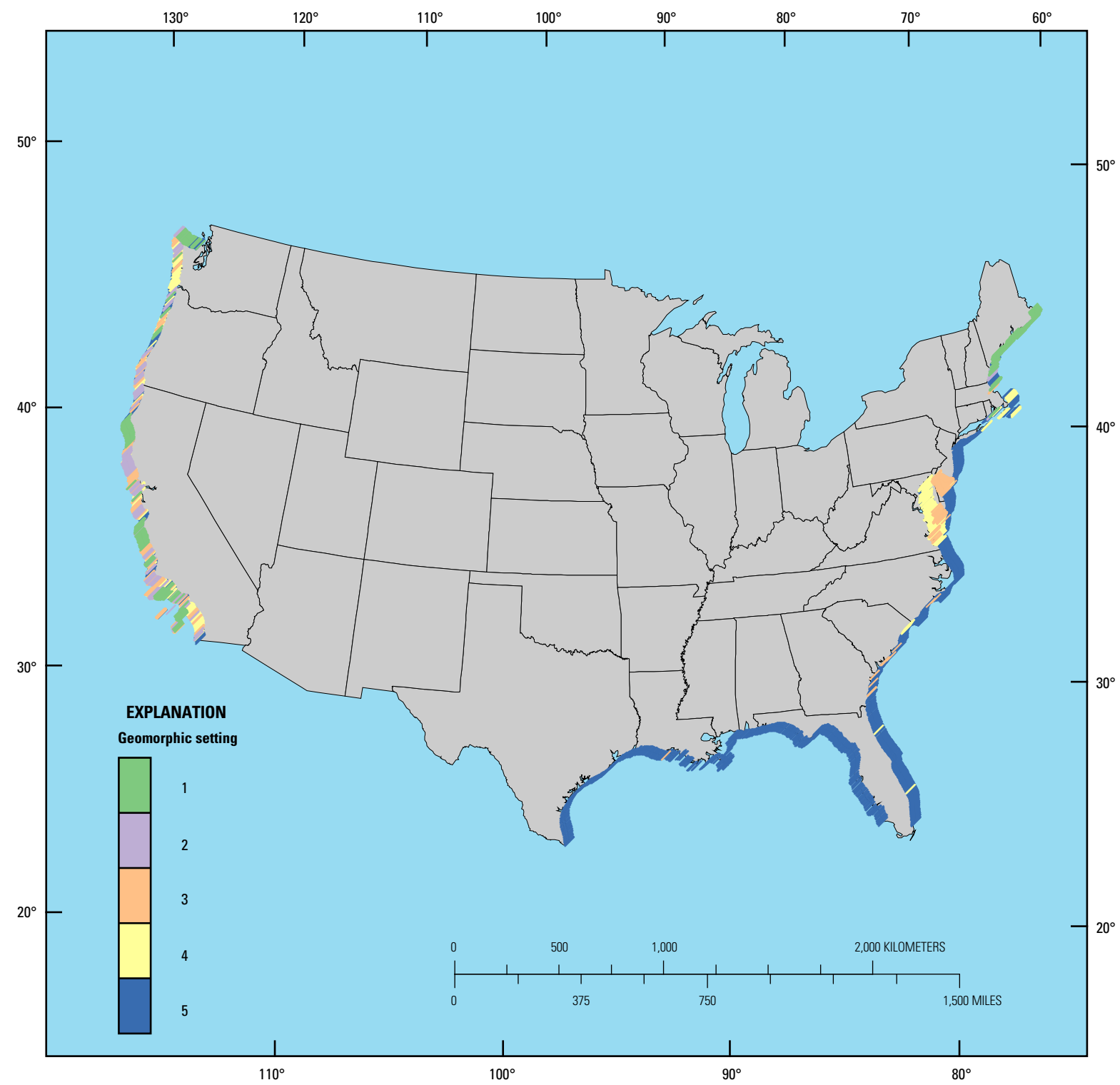

Figure 8. Map of geomorphology classes for the coast of the continental United States showing the extent of the data included in this report. See table 1 for explanation of geomorphic settings. Color scheme defined using Brewer (2013).

relief model were used to calculate slopes for Alaska (Amante and Eakins, 2009). Slopes for Hawaii were determined using the NGDC Coastal Relief Model (NGDC, 2012).

Shoreline-change rate.-For the U.S. Atlantic, Gulf, and Pacific coasts, decadal- to centennialscale shoreline-change rates were based on data compiled by May and others (1983) and Dolan and others (1988), as presented in the Coastal Erosion Information System (CEIS) (May and others, 1982) (figs. 12 and 13). The data in CEIS are drawn from a wide variety of sources, including published reports, historical shoreline-change maps, field surveys, and aerial photo analyses. Shoreline-change rate data along the southern shore of Delaware Bay and the northern Chesapeake Bay were updated with shoreline-change rates from Dolan and Peatross (1992) because of possible gridding errors in the original (Hammar-Klose and Thieler, 2001) dataset, which included an older shoreline-change rate dataset (Dolan and others, 1988). Updated long-term erosion rates are available from other sources (Morton and 

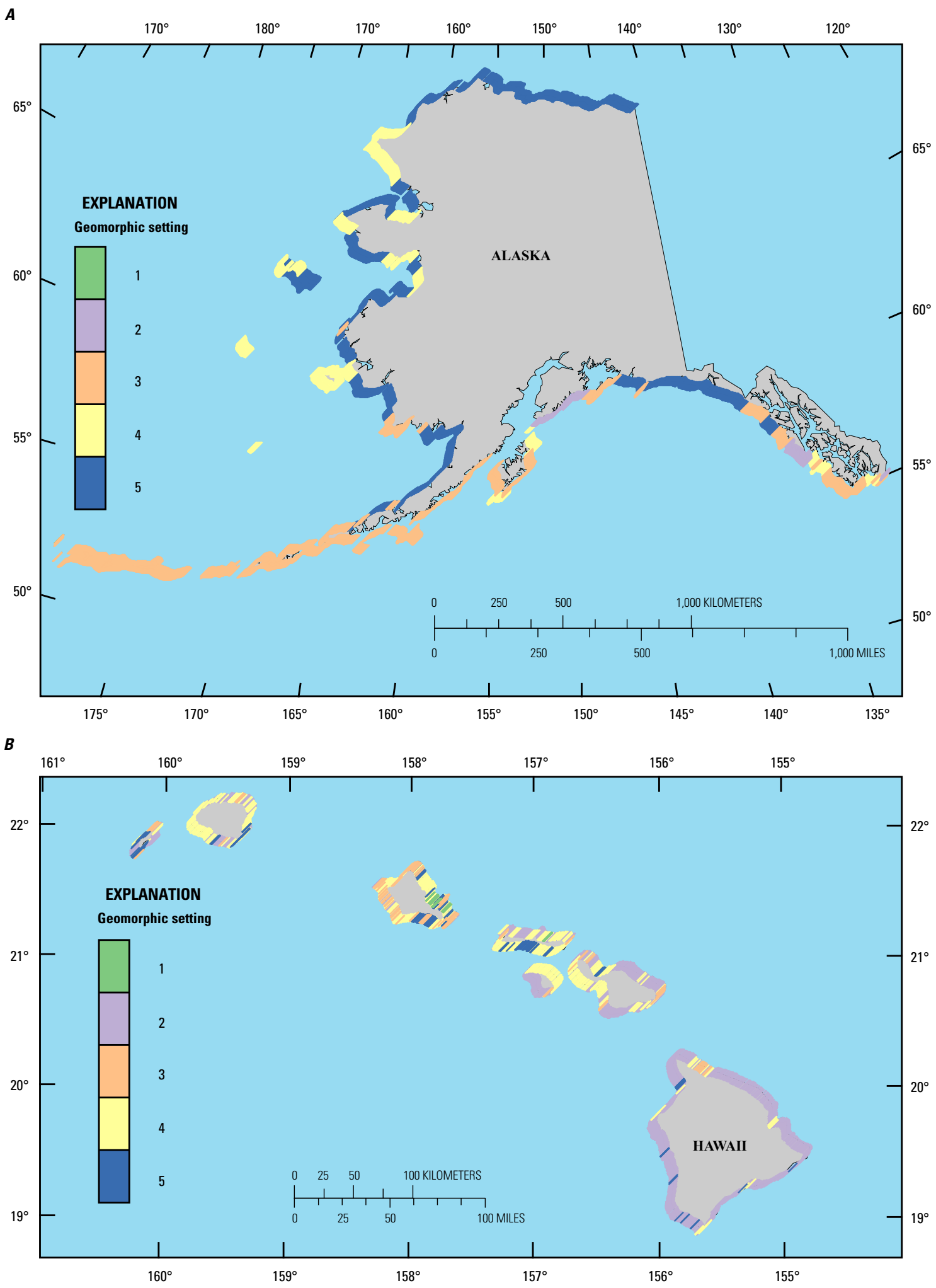

Figure 9. Map of geomorphology classes for the coasts of Alaska $A$ and Hawaii $B$ showing the extent of the data included in this report. See table 1 for explanation of geomorphic settings. Color scheme defined using Brewer (2013). 


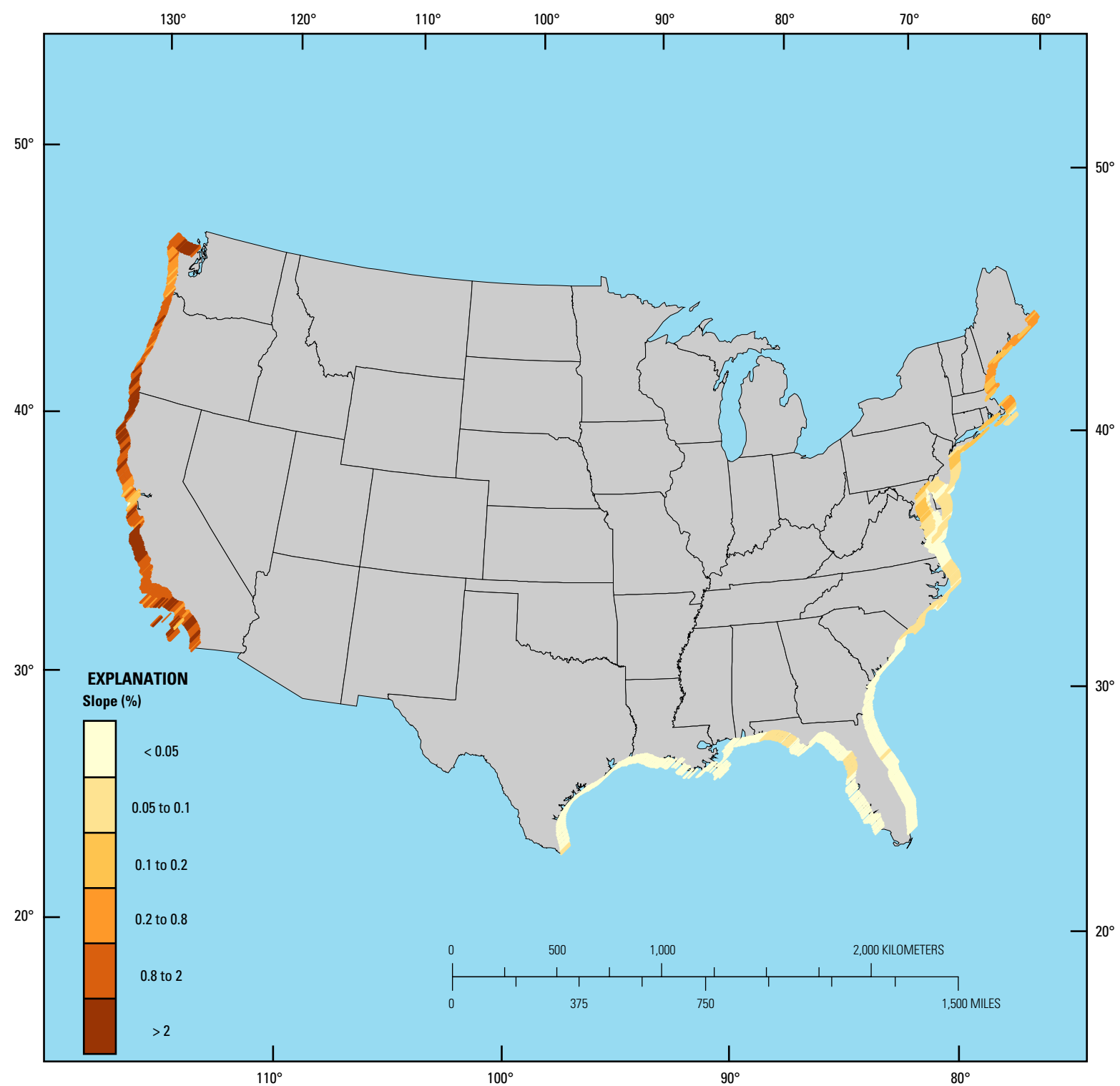

Figure 10. Map of coastal slope classes for the coast of the continental United States showing the extent of the data included in this report. Color scheme defined using Brewer (2013).

Miller, 2005; Hapke and others, 2006 and 2010; Fletcher and others, 2011; Ruggiero and others, 2012), but these datasets are not integrated with the other oceanographic and geologic variables and could not be used at this time. While updated and potentially more accurate shoreline-change data (or any of the other data types) are available, the methods used here extract correlations between all the variables in the $\mathrm{BN}$, and do not actually retain the individual change-rate data. Thus, data errors will, potentially, weaken the correlation estimates that are harnessed by the BN. But, these errors would be reflected in higher levels of uncertainty, which are also predicted by the BN. The resulting predictions will be valid for any subsequent time period assuming that the $\mathrm{BN}$ is capturing correlations based on physical process relationships that are valid and transferable to different locations and different times.

Shoreline-change data for Alaska and Hawaii also were obtained from the same sources used for Hammar-Klose and Thieler (2001) and Dolan and others (1988). These data sources only offered partial 

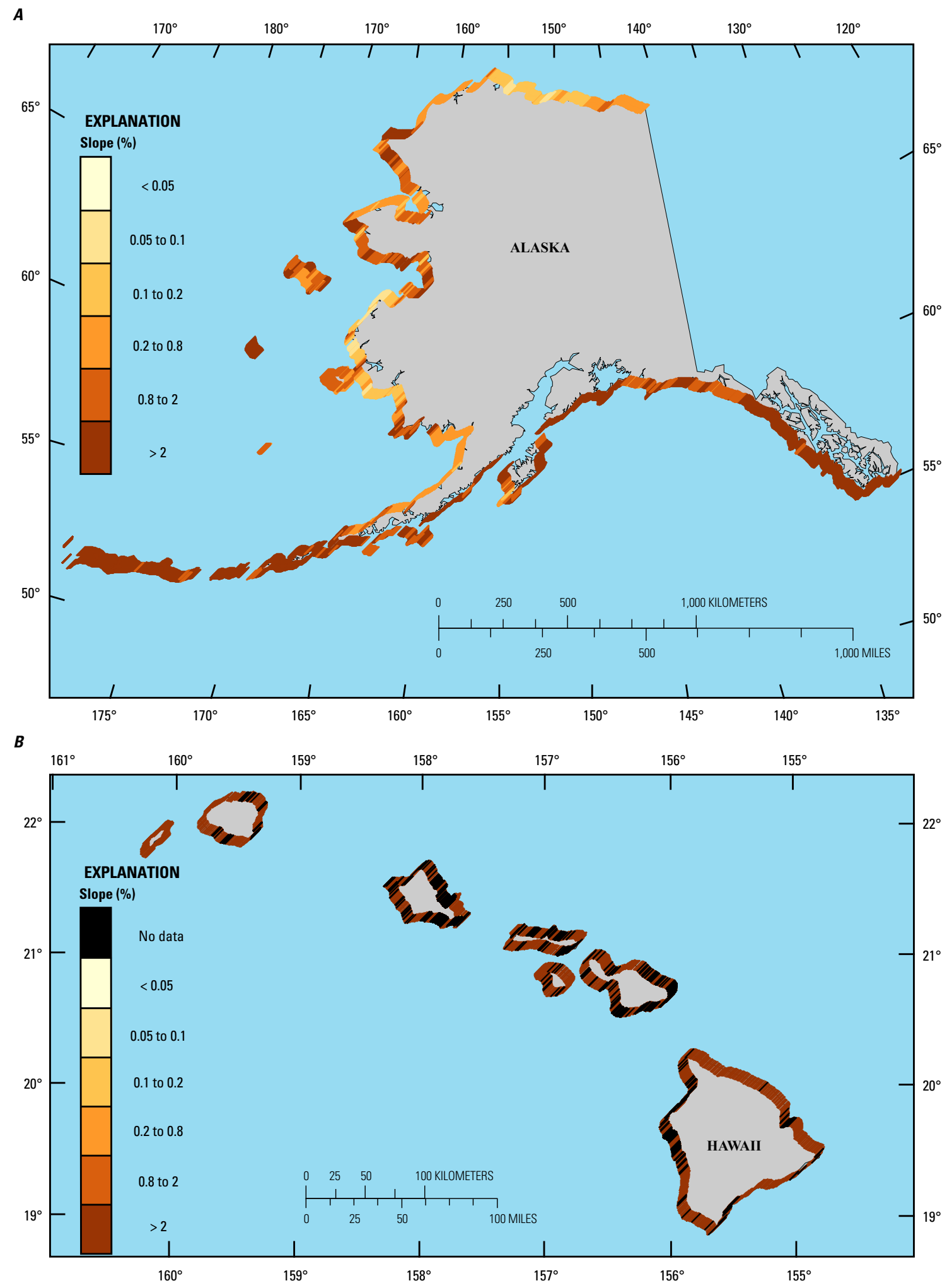

Figure 11. Map of coastal slope classes for the coasts of Alaska $A$ and Hawaii $B$ showing the extent of the data included in this report. Color scheme defined using Brewer (2013). 


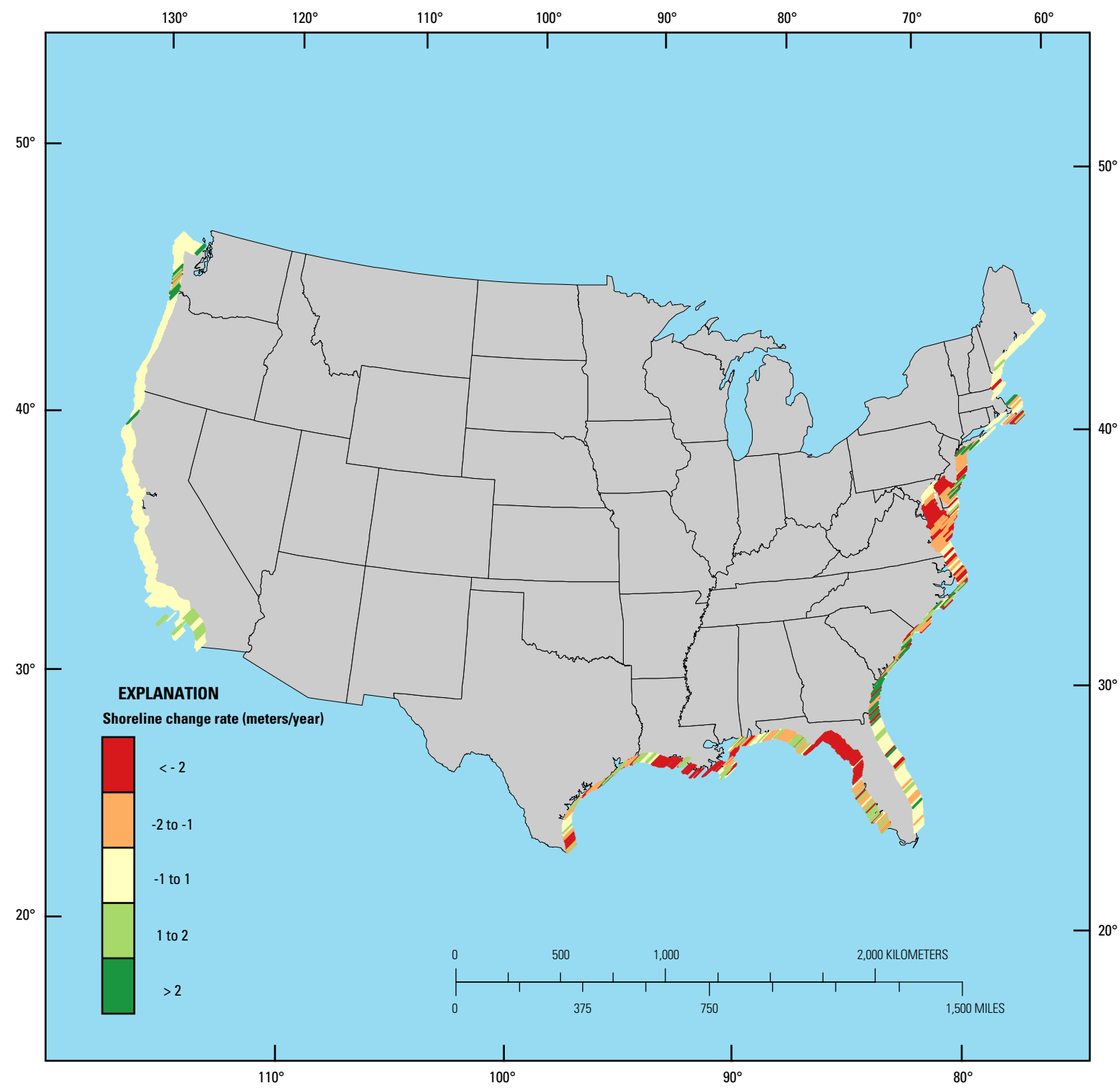

Figure 12. Map of shoreline-change rate classes for the coast of the continental United States showing the extent of the data included in this report. Color scheme defined using Brewer (2013).

coverage of each state. For Alaska, data were available for the north coast region as well as the parts of the shoreline along northwestern Alaska (note non-black areas, fig. 13). For Hawaii, shoreline-change rates were available for portions of Kauai, Oahu, and Maui (note non-black areas, fig. 13).

\section{Results}

Shoreline-change rates can be predicted with the $\mathrm{BN}$ based on learned correlations from the input variables and prior distributions of shoreline-change rates at all locations. Hindcast predictions using input oceanographic and geomorphic data at each location are used to constrain the BN to produce a prediction in the form of an updated conditional probability of shoreline change. Negative shoreline change corresponds to erosion and positive shoreline change corresponds to accretion, with the predictions giving the expected vulnerability under current conditions. The $\mathrm{BN}$ can be updated with future 
A

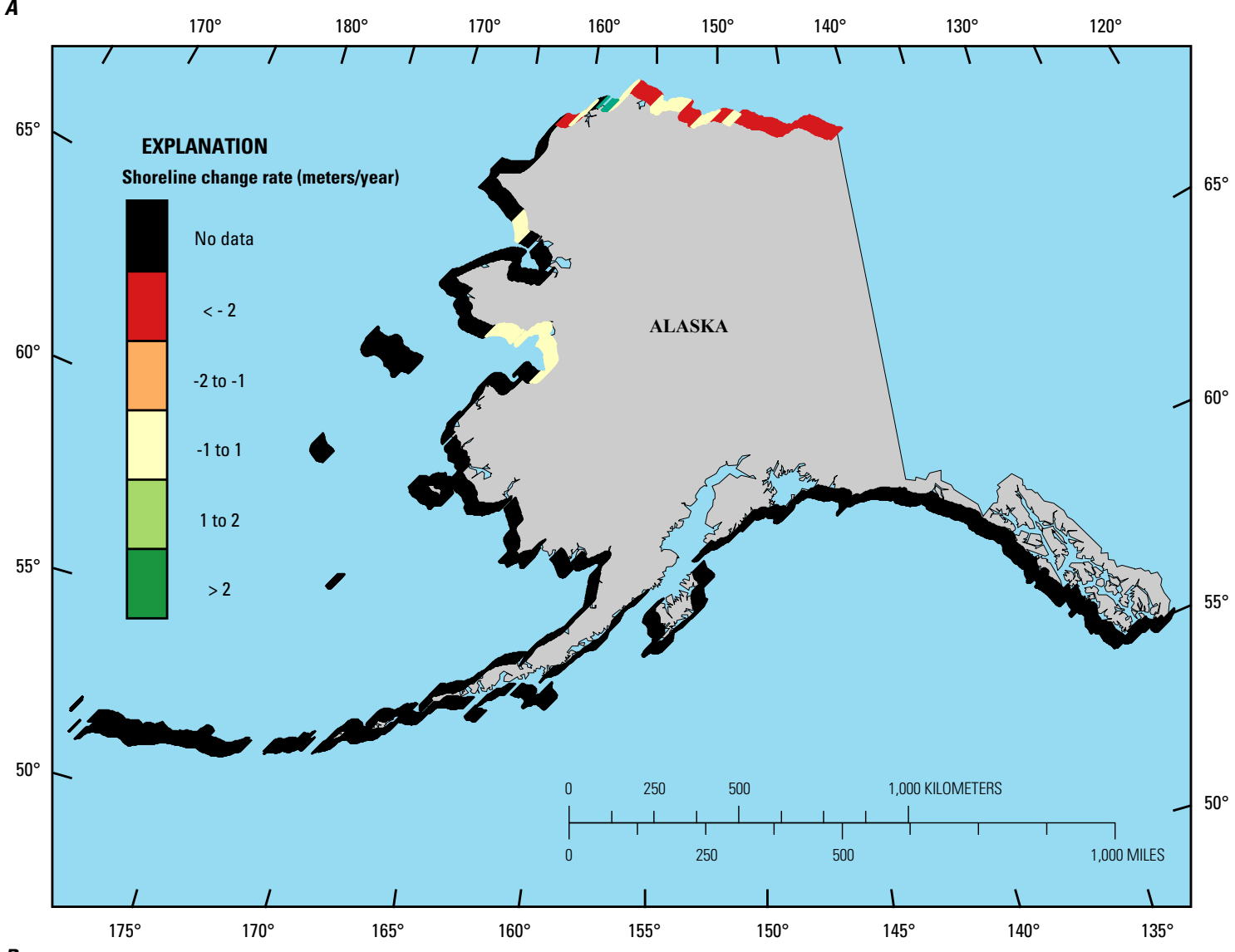

B

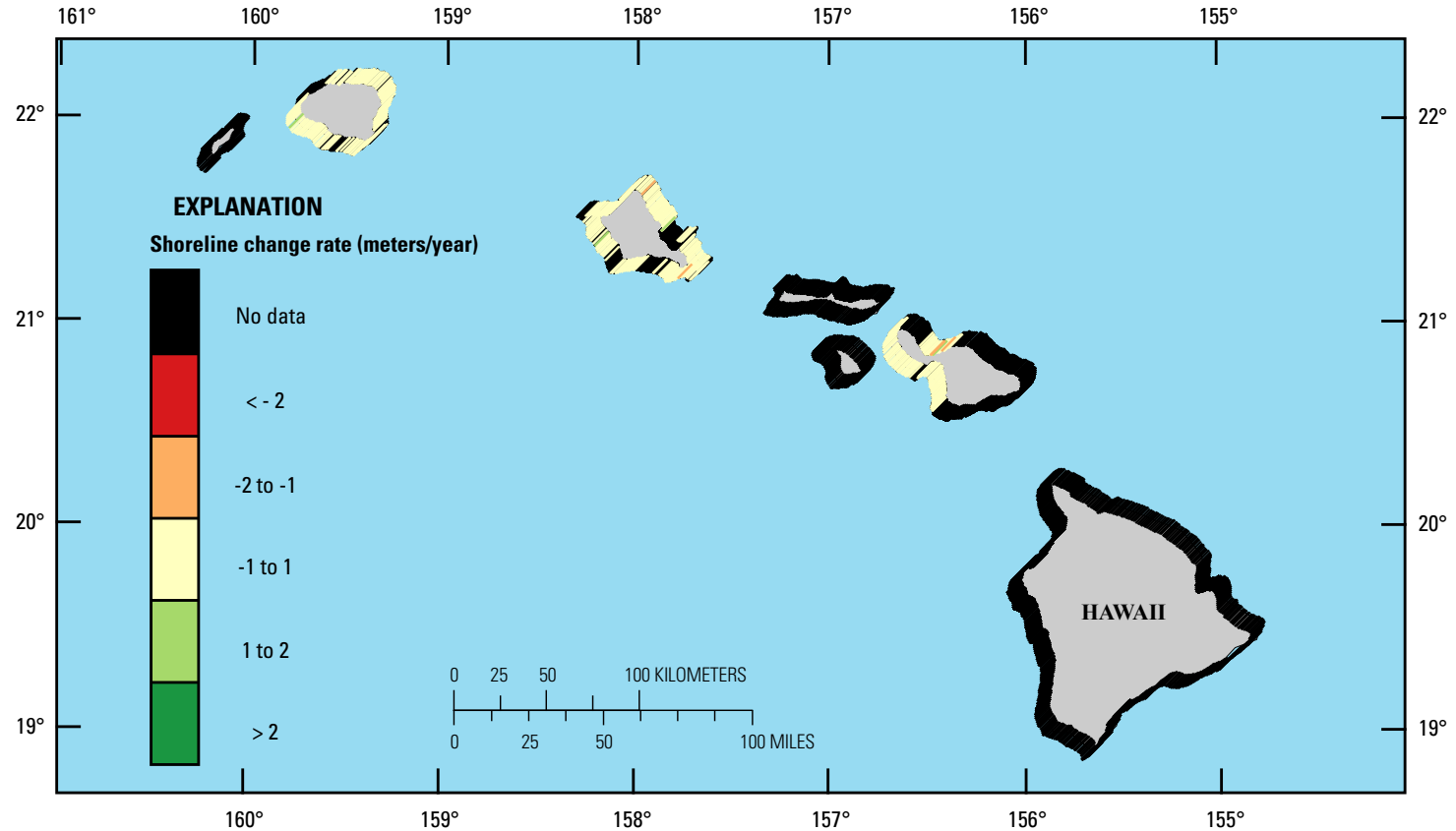

Figure 13. Map of shoreline-change rate classes for the coasts of Alaska $A$ and Hawail $B$ showing the extent of the data included in this report. Color scheme defined using Brewer (2013). 
values of the input variables, and these inputs can include input uncertainty, which, for example, is ideal for handling future sea-level rise projections. Shoreline-change rate predictions can be made even where some or all of the data are missing, as these omissions are accounted for by increases in prediction uncertainty. Our objective is to demonstrate the application and the skill of the approach applied to the existing data.

\section{Bayesian Network Skill}

To evaluate the skill of the $\mathrm{BN}$ in predicting shoreline change we calculated a prediction success rate. Using the updated conditional probability of shoreline change (left hand term of equation 1) based on input at each location in the dataset, the BN prediction was assigned to the most likely outcome (that is, the bin with the greatest posterior probability). The success rate was calculated as the percentage of cases where the observed shoreline-change rate corresponded to the shoreline-change rate bin with the highest predicted probability (that is, the predicted most likely shoreline-change rate). This comparison was calculated only for those cases where shoreline-change observations were present in the dataset $(6,409$ cases). The percentage of cases where the observation fell within a bin that was adjacent to the most likely prediction also was calculated and provides a measure of cases where the prediction was nearly correct. We computed the success rates for the overall dataset and for each coast individually (table 2). Overall, the BN predicted correctly 68 percent of the cases where shoreline-change rate observations were available. When evaluated by individual coasts, the success rates varied from 34 percent for the Gulf coast to 93 percent for the Pacific coast. For cases where adjacent bins were considered the BN success rate was 85 percent for the entire dataset, and ranged from 78 percent for the Gulf coast to 100 percent for the Hawaiian coast indicating that most predictions were within one bin of the observations.

A summary of the maximum probability for each predicted outcome (table 2) quantifies prediction uncertainty, with higher probabilities indicating lower uncertainties for a prediction. The average of the most likely probabilities is highest for the Pacific coast at 92 percent and lowest for the Alaska coast with an average of 42 percent. The higher averages indicate a lower degree of prediction uncertainty. The standard deviations and ranges indicate the variability for each coast with the Gulf coast exhibiting the narrowest probability ranges.

Table 2. Skill scores for Bayesian Network output.

$[(\mathrm{N})=$ number of non-fill value observations that were used in the skill evaluations. $\mathrm{N}=24,007$ for whole dataset. $]$

\begin{tabular}{cccccc}
\hline Coast & Percent & $\begin{array}{c}\text { Percent } \\
\text { Success }\end{array}$ & \multicolumn{3}{c}{ Most likely probability (percent) } \\
\cline { 5 - 6 } & +/- 1 bin & & Mean & Std. Dev. & Range \\
\hline $\begin{array}{c}\text { All coasts } \\
(6,409)\end{array}$ & 68 & 85 & 59 & 36 & $20-100$ \\
$\begin{array}{c}\text { Atlantic Coast } \\
(2,378)\end{array}$ & 65 & 78 & 59 & 21 & $29-100$ \\
$\begin{array}{c}\text { Gulf Coast (566) } \\
\text { Pacific Coast } \\
(1,414)\end{array}$ & 34 & 78 & 56 & 17 & $35-100$ \\
Alaska (1,386) & 93 & 97 & 92 & 14 & $33-100$ \\
Hawaii (665) & 98 & 81 & 42 & 34 & $20-100$ \\
\hline
\end{tabular}




\section{Mapping Predictions}

The BN shoreline-change rate predictions at each location can be visualized as maps of erosion vulnerability. The results are shown in maps depicting the probability of shoreline change (figs. 14 and 15). The probabilities of shoreline-change rates less than $-1 \mathrm{~m} / \mathrm{yr}$ (erosion rates indicating high or very high vulnerability) are mapped (figs. 14 and 15) and the probabilities are color coded according to the IPCC likelihood terms that are used to communicate the likelihood of an outcome (IPCC, 2007b; Gutierrez and others, 2011a).

A summary of the percent of coast where the probability of high and very high erosion rates is 67 percent or greater (corresponding to very likely on the IPCC scale, IPCC 2007a) is shown in table 3. Seven percent of all the coastlines were likely to experience high and very high erosion rates. Thirty percent of the Atlantic coast, 34 percent of the Gulf coast, 0 percent of the Pacific and Hawaii coasts, and 7 percent of the Alaskan coast were predicted to be likely to erode. Compared to the observations used to train the BN, high and very high erosion are under predicted by the BN for all regions. The disparity is largest for the Gulf and Alaska coasts.

Table 3. Percent of coast where shoreline-change rate indicating erosion (at least - $1 \mathrm{~m} / \mathrm{yr}$ ) is likely (probability of at least 67 percent).

\begin{tabular}{ccc}
\hline Coast & Percent for all cases & Observed $^{*}$ \\
\hline All coasts & 7 & 31.0 \\
Atlantic coast & 30 & 42.2 \\
Gulf coast & 34 & 65.4 \\
Pacific coast & 0 & 1.3 \\
Alaska & 7 & 42.6 \\
Hawaii & 0 & 1.0 \\
*percent of observed values where an observation is available
\end{tabular}

The prediction uncertainty at each location can be displayed as well. Figures 16 and 17 show the probability of the most likely shoreline-change rate prediction at each location. When the probability of the most likely prediction reaches higher values, this indicates a more certain prediction. Lower probabilities indicate less certain predictions. Since values in our shoreline-change node were divided into five bins, total uncertainty would be indicated when the most likely prediction probabilities approached 20 percent in all five bins. The mean value of the most likely probability for all coastlines was 59 percent, individually the Atlantic coast was 59 percent, Gulf coast was 56 percent, Pacific coast was 92 percent, Hawaiian coasts were 42 percent, and the Alaskan coast was 77 percent (table 2). 


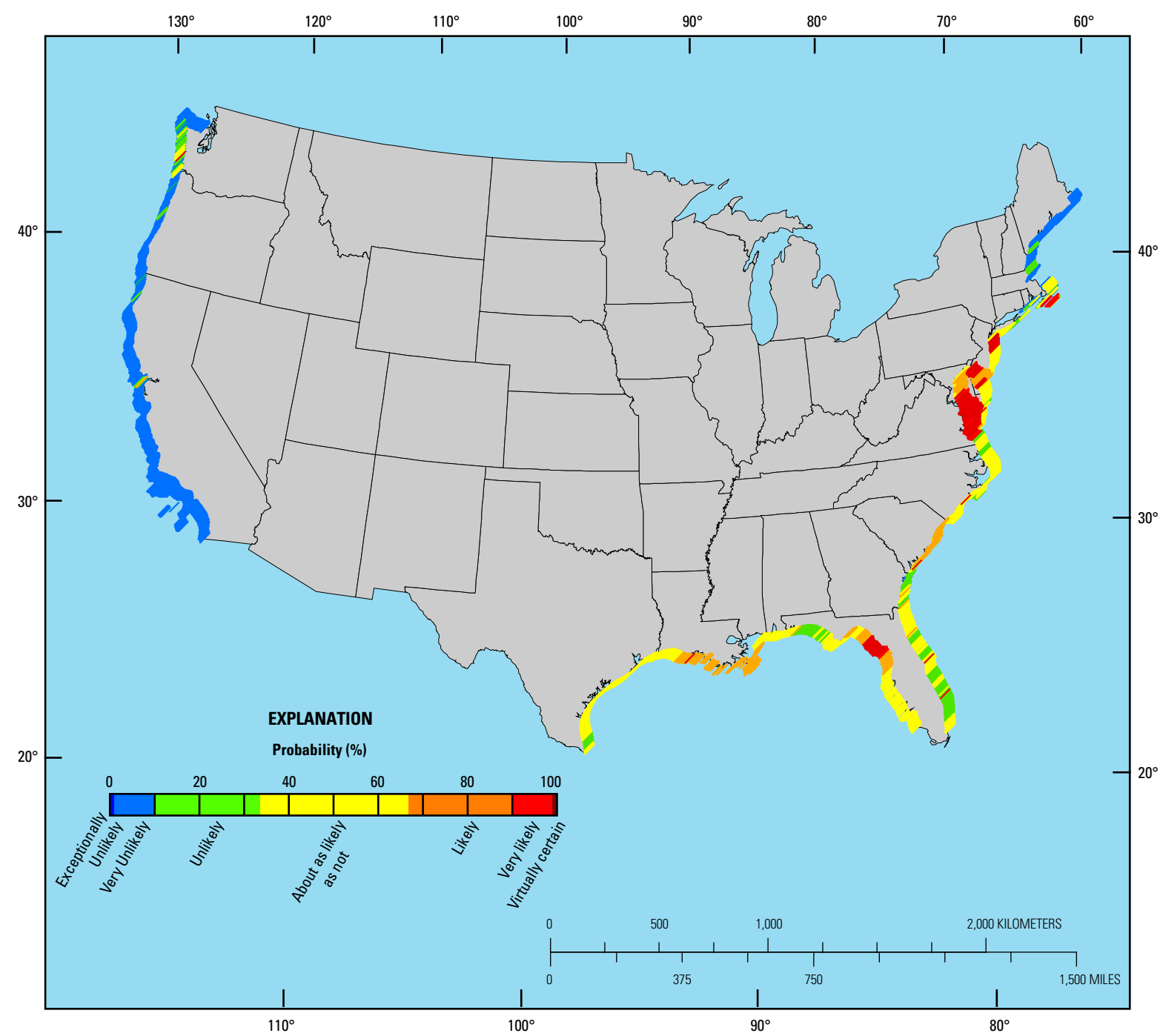

Figure 14. Maps of the continental U.S. coasts showing the posterior probability of shoreline-change rates $<-1$ meter per year. The probabilities are color coded, and labeled using Intergovernmental Panel on Climate Change (IPCC) likelihood terminology (Intergovernmental Panel on Climate Change, 2007b).

\section{Discussion and Summary}

In this report, we expand on the work of Gutierrez and others $(2011 \mathrm{a}, \mathrm{b})$ and presented oceanographic and geomorphic datasets and $\mathrm{BN}$ predictions of shoreline-change rate probabilities for the coastlines of the continental United States, Alaska, and Hawaii. This analysis is new because it provides probabilistic predictions where some data may be missing, such as in parts of Alaska and Hawaii, and can be updated with additional geomorphic and oceanographic data that may be obtained from new observations or models. Uncertainty in the inputs, particularly those variables associated directly with climate change (for example, sea-level rise), can be included in the predictions.

Hindcast predictive skill was tested by assessing the percentage of correctly predicted shorelinechange rates. This predictive skill test indicated that the BN performance, at 68 percent for the entire dataset, was less skillful than Gutierrez and others (2011a) reported for the entire dataset with a success rate of 77 percent. BN performance varied regionally, with the Atlantic, Pacific, and Hawaiian coasts achieving success rates of 65 percent or greater, and the Gulf and Alaskan coasts achieving lower scores 

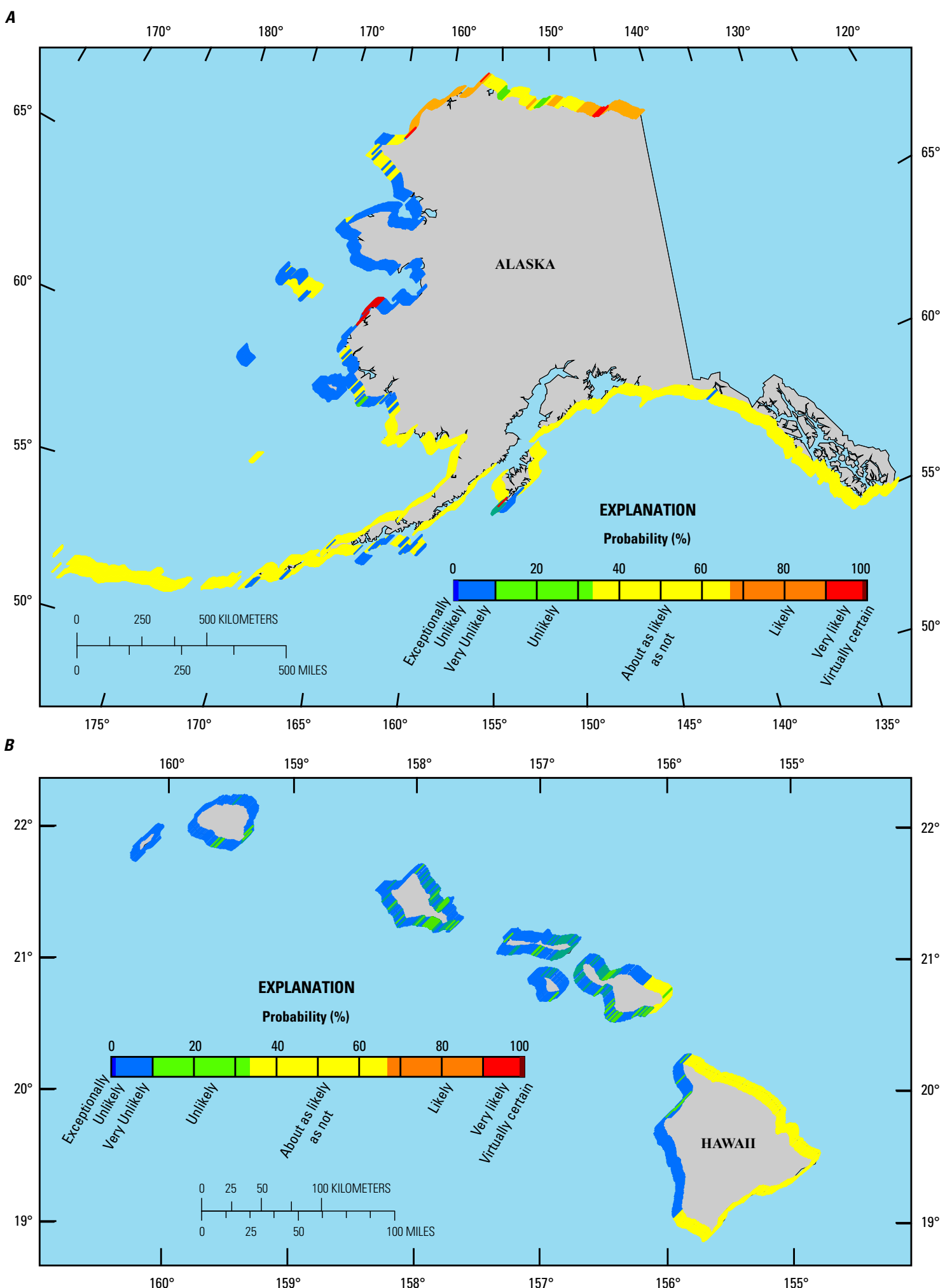

Figure 15. Maps of Alaska $A$ and Hawaii $B$ showing the posterior probability of shoreline-change rates $<-1$ meters per year. The probabilities are color coded, and labeled using Intergovernmental Panel on Climate Change (IPCC) likelihood terminology (Intergovernmental Panel on Climate Change, 2007b). 


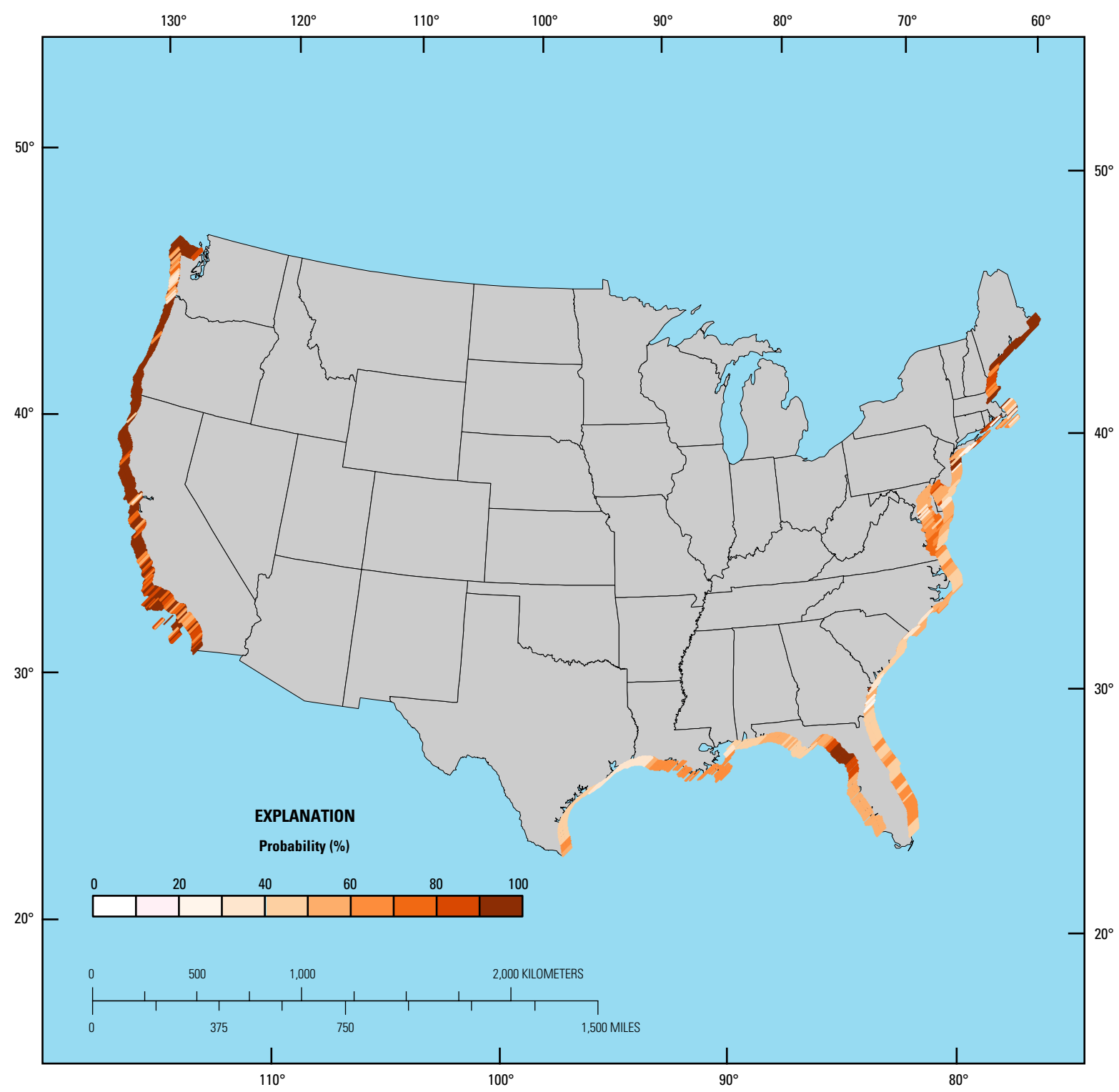

Figure 16. Maps of the continental U.S. coasts showing the probability of the most likely shoreline-change rate. Color scheme defined using Brewer (2013).

of 34 and 46 percent, respectively. When predictions that fell within one bin (out of five) of the observations were counted, success rates increase to 85 percent for the entire dataset and were nearly 80 percent in all regions. The regional variations in success rate were generally related to regional variations in prediction uncertainty with the highest success rates corresponding to higher mean probabilities for each coast and vice versa. 

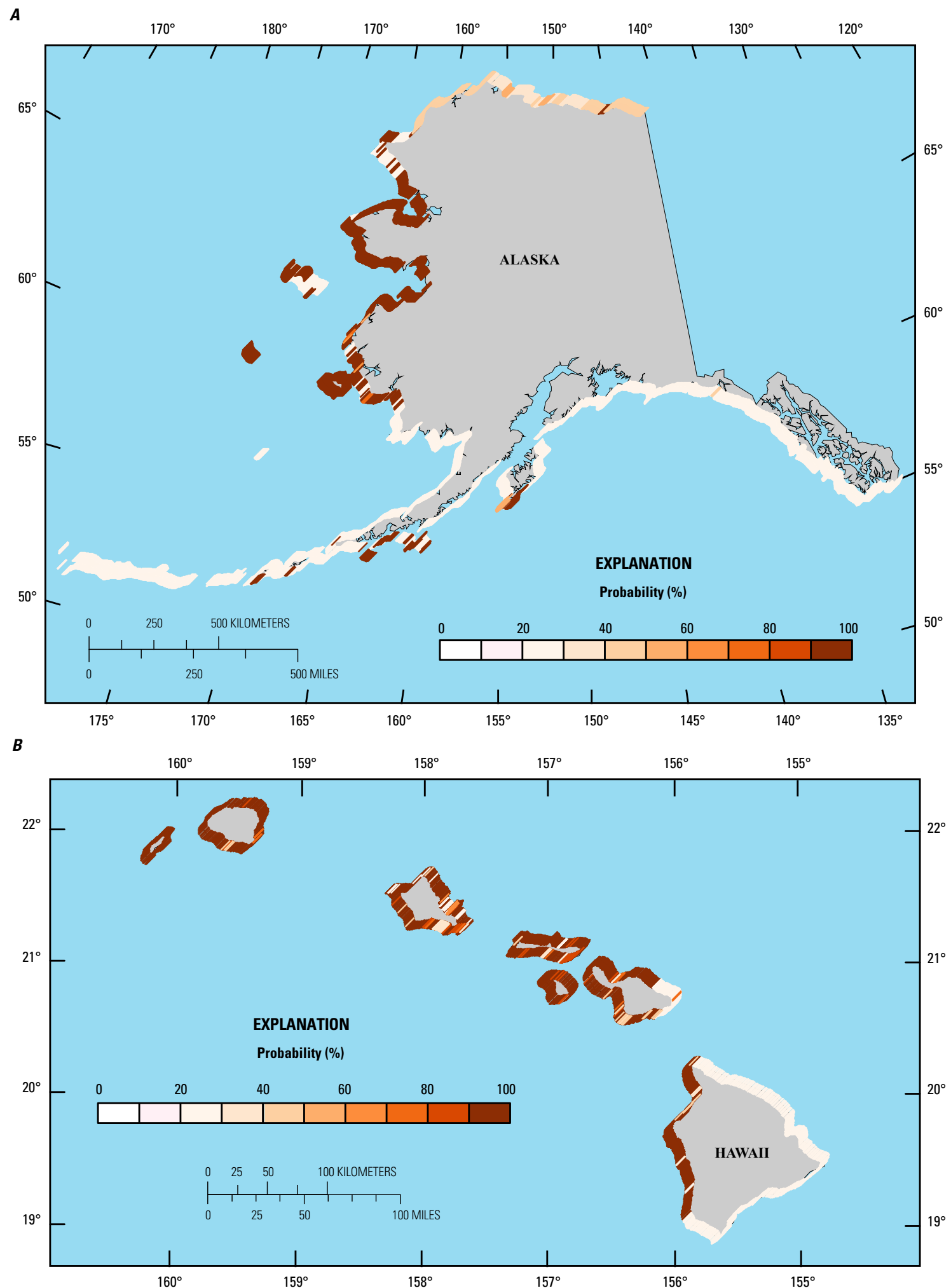

Figure 17. Maps of Alaska $A$ and Hawaii $B$ showing the probability of the most likely shoreline-change rate. Color scheme defined using Brewer (2013). 


\section{Acknowledgments}

This work was funded by the USGS Coastal and Marine Geology and Global Change Research Programs. We thank Li Erikson and Cheryl Hapke for their reviews and feedback on this report. We also thank Meredith Kratzmann and Emily Himmelstoss for their assistance with figure and metadata revisions. Additional editorial review by Bruce Taggert further improved manuscript clarity.

\section{References Cited}

Amante, C., and Eakins, B.W., 2009, ETOPO1 1 Arc-Minute Global Relief Model-Procedures, data sources and analysis: NOAA Technical Memorandum NESDIS NGDC-24, 19 p., accessed March 2009 at http://www.ngdc.noaa.gov/mgg/global/global.html.

Bayes, T., 1763, An essay towards solving a problem in the doctrine of chances: Philosophical Transactions of the Royal Society of London, p. 330-418. (Reprinted by Barnard, G.A., 1958, Biometrika, v. 45, p. 293-315).

Brewer, Cynthia A., 2013, Color advice for cartography, ver. 2.0: accessed September 10, 2013, at http://colorbrewer2.org/.

Climate Change Science Program (CCSP), 2009, Coastal sensitivity to sea-level rise-A focus on the mid-Atlantic region: A report by the Climate Change Science Program and the subcommittee on Global Change Research. James G. Titus (Coordinating Lead Author), U.S. Environmental Protection Agency, Washington D.C., USA, 320 p.

Dolan, R., Anders, F., and Kimball, S., 1988, Coastal Erosion and Accretion-National Atlas of the United States of America, U.S. Geological Survey, Reston, Virginia, 1 sheet.

Dolan, R., and Peatross, J., 1992, Data supplement to the U.S. Geological Survey 1:2,000,000-scale map of shoreline erosion and accretion of the mid-Atlantic Coast: U.S. Geological Survey Open-File Report 92-377, $116 \mathrm{p}$.

Fletcher, C.H., Romine, B.M., Genz, A.S., Barbee, M.M., Dyer, M., Anderson, T.R., Lim, S.C., Vitousek, S., Bochicchio, C., and Richmond, B.M., 2011, National assessment of shoreline change-Historical shoreline change in the Hawaiian Islands: U.S. Geological Survey Open-File Report 2011-1051, 55 p., available at http://pubs.usgs.gov/of/2011/1051.

Gelman, A., Carlin, J.B., Stern, H.S., and Rubin, D.B., 2004, Bayesian data analysis, (2d ed.): New York, Chapman \& Hall, 668 p.

Gutierrez, B.T., Plant, N.G., and Thieler, E.R., 2011a, A Bayesian network to predict coastal vulnerability to sea level rise: Journal of Geophysical Research Earth Surface, v. 116, doi:10.1029/2010JF001891, available at $\underline{\text { ttp: } / / d x \text {.doi.org/10.1029/2010JF001891. }}$.

Gutierrez, B.T., Plant, N.G., and Thieler, E.R., 2011b, A Bayesian Network to predict vulnerability to sea-level rise: data report, U.S. Geological Survey Digital Data Series 601, 15 p., available at http://pubs.usgs.gov/ds/601/. 
Gutierrez, B.T., Williams, S.J., and Thieler, E.R., 2009, Appendix 2-Basic approaches for shoreline change protections, in - Coastal sensitivity to sea-level rise: a focus on the mid-Atlantic region. A report by the Climate Change Science Program and the subcommittee on Global Change Research. James G. Titus (Coordinating Lead Author), U.S. Environmental Protection Agency, Washington D.C., USA, 320 p.

Hammar-Klose, E., and Thieler, E.R., 2001, Coastal vulnerability to sea-level rise-A preliminary database for the U.S. Atlantic, Pacific, and Gulf of Mexico coasts: U.S. Geological Survey, Digital Data Series, DDS-68, available at http://pubs.usgs.gov/dds/dds68/.

Hapke, C.J., Reid, D., Richmond, B.M., Ruggiero, P. and List, J., 2006, National assessment of shoreline change-Part 3, historical shoreline change and associated land loss along sandy shorelines of the California coast: U.S. Geological Survey, Open-File Report, 2006-1219, 72 p., available at http://pubs.usgs.gov/of/2006/1219/.

Hapke, C.J., Himmelstoss, E.A., Kratzmann, M.G., List, J.H., and Thieler, E.R., 2010, National assessment of shoreline change: historical shoreline change along the New England and Mid-Atlantic coasts: U.S. Geological Survey Open-File Report 2010-1118, 57 p., available at http://pubs.usgs.gov/ of/2010/1118/.

Holgate, S.J., Matthews, A., Woodworth, P.L., Rickards, L.J., Tamisiea, M.E., Bradshaw, E., Foden, P.R., Gordon, K.M., Jevrejeva, S., and Pugh, J., 2013, New data systems and products at the Permanent Service for Mean Sea Level: Journal of Coastal Research, v. 29, no. 3, p. 493-504, available at http://dx.doi.org/10.2112/JCOASTRES-D-12-00175.1.

Hubertz, J.M., Thompson, E.F., and Wang, H.V. 1996, Wave Information Studies of U.S. coastlinesAnnotated bibliography on coastal and ocean data assimilation: WIS Report 36, Vicksburg, Mississippi, U.S. Army Engineer Waterways Experiment Station, 31 p.

Intergovernmental Panel on Climate Change (IPCC), 2007a, The Physical Science Basis. Contribution of Working Group I to the Fourth Assessment Report of the Intergovernmental Panel on Climate Change, Solomon, S., D. Qin, M. Manning, Z. Chen, M. Marquis, K.B. Averyt, M. Tignor and H.L. Miller (eds.). Cambridge University Press, Cambridge, United Kingdom and New York, NY, USA, 996 p.

Intergovernmental Panel on Climate Change (IPCC), 2007b, Synthesis Report. Contribution of Working Groups I, II, and III to the fourth assessment report of the Intergovernmental Panel on Climate Change, Core writing team: Pachauri, R.K. and Reiseinger, A. (eds.). IPCC Geneva, Switzerland, 104 p.

Jensen, F.V., and Nielsen, T.D., 2007, Bayesian networks and decision graphs: New York, N.Y., Springer Verlag, $447 \mathrm{p}$.

Leatherman, S.P., 2001, Social and economic costs of sea level rise, in, Douglas, B.C., Kearney, M.S., and Leatherman, S.P. (eds.), Sea level rise-History and consequences: San Diego, California, Academic Press, p. 181-223.

May, S.K., Dolan, R., and Hayden, B.P. 1983, Erosion of U.S. shorelines: EOS Transactions of the American Geophysical Union, v. 6435, p. 521-523.

May, S.K., Kimball, W.H., Grady, N., and Dolan, R., 1982, CEIS-The coastal erosion information system: Shore and Beach, v. 50, p. 19-26. 
Morton, R.A., and Miller, T.L., 2005, National assessment of shoreline change-Part 2-Historical shoreline changes and associated coastal land loss along the U.S. Southeast Atlantic Coast:

U.S. Geological Survey Open-File Report, 2005-1401, 35 p., available at http://pubs.usgs.gov/ of/2005/1326/.

National Climate Assessment (NCA), 2013, The Third National Climate Assessment, accessed May 2013 at http://www.globalchange.gov/about.html.

National Geophysical Data Center (NGDC), 2012, U.S. Coastal Relief Model, accessed May 2012 at http://www.ngdc.noaa.gov/mgg/coastal/crm.html.

National Ocean Service (NOS), 2013, Datums - Station Selection, accessed May 2013 at http://tidesandcurrents.noaa.gov/stations.html? type =Datums.

Norsys, 1992-2009, Netica version 4.09, Accessed, May 2009, http://www.norsys.com.

Permanent Service for Mean Sea Level (PSMSL), 2013, Obtaining Tide Gauge Data, accessed May 2013 at http://www.psmsl.org/data/obtaining/.

Ruggiero, P., Kratzmann, M.G., Himmelstoss, E.A., Reid, D., Allan, J., and Kaminsky, G., 2012, National assessment of shoreline change-Historical shoreline change along the Pacific Northwest coast: U.S. Geological Survey Open-File Report 2012-1007, 62 p., available at http://dx.doi.org/10.3133/ofr20121007.

Sherrod, D.R., Sinton, J.M., Watkins, S.E., and Brunt, K.M., 2007, Geologic Map of the State of Hawai'i: U.S. Geological Survey Open-File Report 2007-1089, available at http://pubs.usgs.gov/of/2007/1089/.

Thieler, E.R. and E.S. Hammar-Klose, E. 1999, National assessment of coastal vulnerability to future sea-level rise-Preliminary results for U.S. Atlantic Coast: U.S. Geological Survey Open-File Report 99-593.

Wave Information Study (WIS), 2013, U.S. Army Corps of Engineers Wave Information Studies, accessed November 2012 through May 2013 at http://wis.usace.army.mil/.

U.S. Geological Survey (USGS), 1996, Physiographic Divisions of Alaska: Anchorage, Alaska, 1:2,500,000, geospatial data, accessed May 2012 at

http://agdc.usgs.gov/data/usgs/erosafo/physio/metadata/physio.html. 


\section{Appendix 1}

\section{Geospatial Data}

Data used for this analysis are available as a downloadable file that includes input data and output probabilities calculated using the Bayesian network (Link to Metadata in on-line version: for review see "ProbSLC_US_Data.html"). All vector data are delivered as ESRI shapefiles in the geographic coordinate system (WGS84) and distributed with Federal Geographic Data Committee (FGDC) compliant metadata in Extensible Markup Language (*.xml) format. Tabular data are delivered as dBase IV (*.dbf) structured files, which can be read with ESRI ArcGIS software as well as many other available spreadsheet programs. Metadata also are provided for all spatial and tabular data in text (*.txt) and FGDC Classic $(* . h t m l)$ format. ESRI ArcCatalog 9.x or higher also can be used to examine the metadata in a variety of additional formats.

The data provided with this report consist of a shape file and accompanying spreadsheet that contain input data for each location as well as the corresponding output, which consist of discrete shoreline-change rate probability density distributions. As described in the "Dataset Description", the data for the Atlantic coast was obtained from (Gutierrez and others, 2011b), whereas data from Gulf and Pacific coasts were obtained from (Thieler and Hammar-Klose, 1999) and modified so that included data depicted only the open ocean coasts. Data for Alaska and Hawaii were obtained from newer data sources, but processed according to methods applied in (Thieler and Hammar-Klose, 1999) (see "Methods" section) Each set of input values for each location were evaluated using the BN to produce the output probability distributions.

Input data consist of ten fields:

1. ID

2. Decimal longitude

3. Decimal latitude

4. Slope (in percent)

5. Geomorphology

6. Tidal Range (in meters)

7. Rate of relative sea-level rise (in millimeters per year)

8. Mean Wave Height (in meters)

9. Erosion rate (in meters per year)

10. Coast

Output probability distributions consist of five probability classes. There are two extra fields listed that summarize the total probability of erosion and the maximum probability for the five probability classes: fields:

11. pErosion2: probability of shoreline change $<-2$ meters/year

12. pErosion 1: $-2 \mathrm{~m} / \mathrm{yr}<$ probability of shoreline change $<-1$ meters $/ \mathrm{yr}$

13. pStable: $-1 \mathrm{~m} / \mathrm{yr}<$ probability of shoreline change $<1$ meters/yr

14. pAccretion 1: $1 \mathrm{~m} / \mathrm{yr}<$ probability of shoreline change $<2$ meters $/ \mathrm{yr}$

15. pAccretion2: probability of shoreline change $>2$ meters/yr

16. pE_tot: probability of erosion $<-1$ meters/yr

17. pMax: maximum probability of shoreline change 


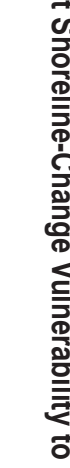

政

